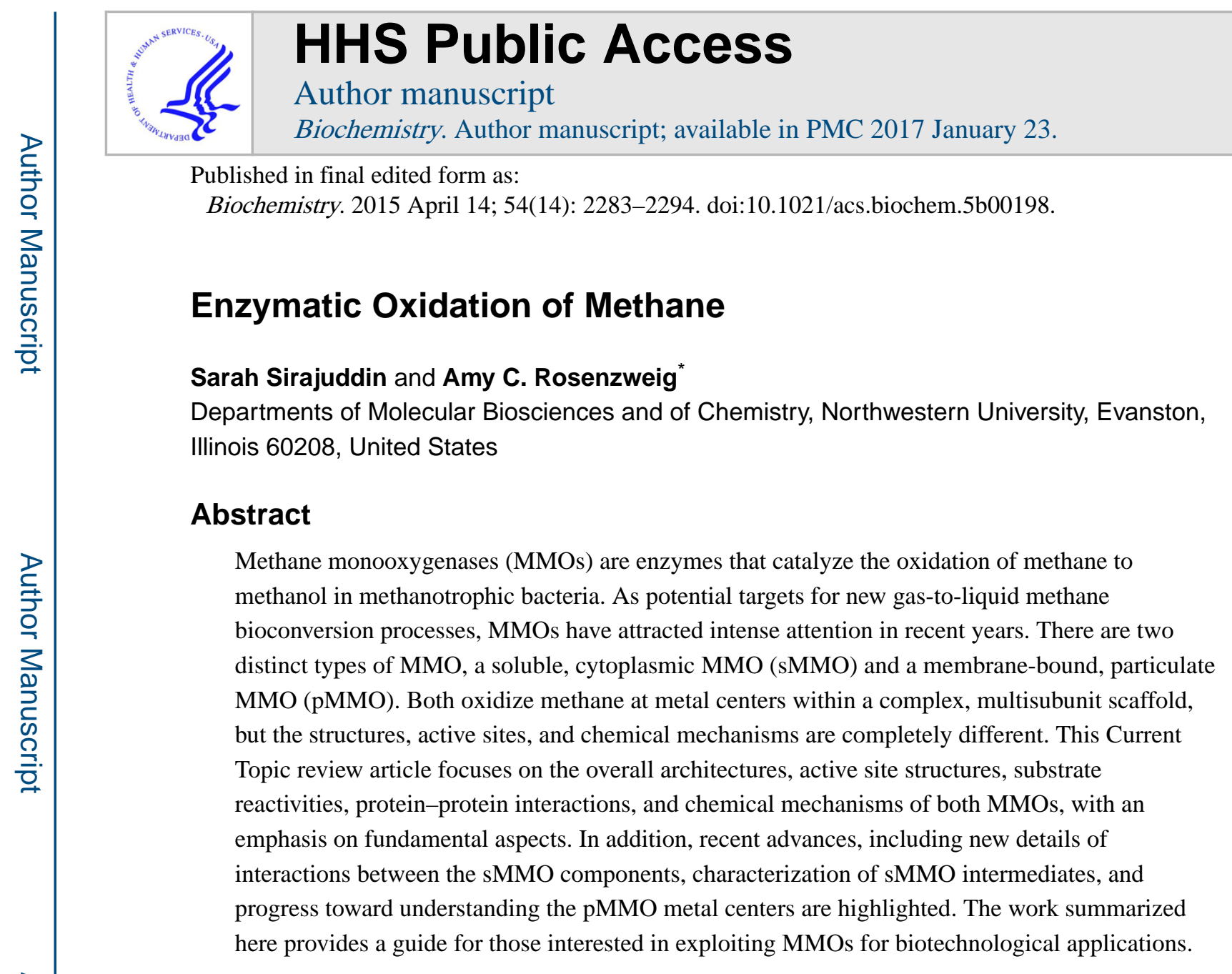

Graphical abstract

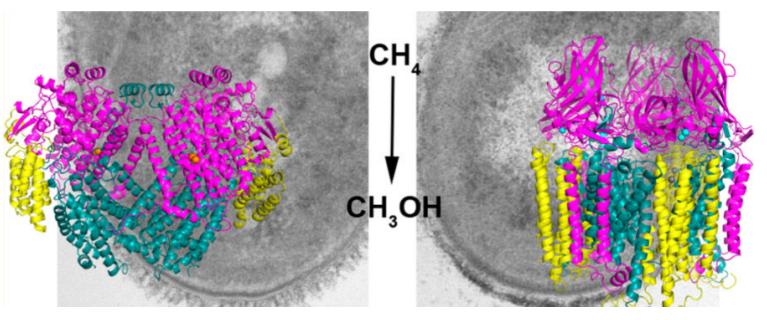

Aerobic methane oxidation in nature is carried out by methanotrophic bacteria, organisms that can use methane as their sole source of carbon and energy. Despite the extremely strong $\mathrm{C}-\mathrm{H}$ bond in methane $\left(\Delta H_{298}=105 \mathrm{kcal} / \mathrm{mol}\right),{ }^{1}$ these bacteria are capable of oxidizing methane to methanol under ambient conditions using metalloenzymes called methane monooxygenases (MMOs). Understanding the biochemistry of MMOs is critical to their applications in bioremediation ${ }^{2}$ and to the development of biological processes for conversion of natural gas to liquid fuels and chemicals. ${ }^{3}$ Moreover, detailed characterization of MMO active sites may lead to new biomimetic catalysts. ${ }^{4} \mathrm{~A}$ range of alkane-oxidizing enzymes exist in the environment, ${ }^{5}$ but only the two types of MMO, soluble MMO (sMMO)

\footnotetext{
*Corresponding Author: amyr@northwestern.edu.
} The authors declare no competing financial interest. 
and particulate MMO (pMMO), as well as the close pMMO homologue ammonia monooxygenase (AMO),${ }^{6}$ can oxidize methane. Although sMMO and pMMO perform the same chemical reaction, their structures, cofactor requirements, and mechanisms are completely different.

sMMO requires three protein components for activity: a hydroxylase (MMOH, $251 \mathrm{kDa})$, a reductase (MMOR, $38.5 \mathrm{kDa}$ ), and a regulatory protein (MMOB, $15.9 \mathrm{kDa}){ }^{7} \mathrm{MMOH}$ is responsible for methane oxidation and is composed of $\alpha, \beta$, and $\gamma$ subunits encoded by the mmoX, mmoY, and mmoZ genes, respectively. MMOB and MMOR are encoded by the $m m o B$ and $m m o C$ genes. The pMMO hydroxylase consists of the pmoB, pmoA, and pmoC subunits, encoded by the pmoCAB operon (Figure 1). ${ }^{8}$ No regulatory protein has been identified for pMMO, and the identity of its native reductase remains unclear. ${ }^{9}$ Most methanotrophs express only pMMO. A few species express only sMMO, and a subset contains genes for both pMMO and sMMO ${ }^{10}$ In this subset, sMMO expression occurs when copper levels in the growth medium are below $1 \mu \mathrm{M}$, and pMMO expression is predominant at copper levels above $5 \mu \mathrm{M} .{ }^{11-13}$ This "copper switch" parallels the metal cofactor requirements of the MMOs: sMMO has a catalytic diiron center, ${ }^{14}$ and pMMO utilizes a copper active site. ${ }^{9}$ The mechanism of the copper switch is still unknown, but recent work suggests that the copper-chelating natural product methanobactin, genes encoded by the methanobactin operon, and $\mathrm{mmoD}$, a gene product of unknown function encoded by the sMMO operon, could play a role. ${ }^{15,16} \mathrm{~A}$ transcriptional activator, mmoR, and a GroEL-like chaperone protein, mmoG (Figure 1), are required for sMMO expression. ${ }^{17,} 18$

Studies of both MMOs over the past quarter century have provided much insight into their structure and function. This Current Topic summarizes work addressing the architecture, active sites, substrate reactivities, protein-protein interactions, and chemical mechanisms of both systems, with emphasis on fundamental aspects that must be considered if MMOs are to be exploited in new gas-to-liquid methane bioconversion processes. In addition, recent advances that have not been reviewed previously are highlighted. A more comprehensive review is available elsewhere. ${ }^{19}$

\section{ENZYME ARCHITECTURE}

\section{Soluble MMO}

To date there are 28 crystal structures of $\mathrm{MMOH}$, primarily from Methylococcus capsulatus (Bath), one structure of the MMOH-MMOB complex, two NMR structures of MMOB, and two NMR structures of MMOR (Table 1). The first crystal structure of MMOH was determined in 1993, and a resolution of $1.7 \AA$ has been achieved. ${ }^{20,} 21$ The a $(60.6 \mathrm{kDa}), \beta$ $(45.1 \mathrm{kDa})$, and $\gamma(19.8 \mathrm{kDa})$ subunits are arranged as an $\alpha_{2} \beta_{2} \gamma_{2}$ dimer composed mainly of $a$-helices except for two $\beta$ hairpins in the $a$ and $\gamma$ subunits (Figure 2A). The dimer interface involves interactions between the $\alpha$ and $\beta$ subunits, and a canyon region formed by the $\alpha$ and $\beta$ subunits in each $\alpha \beta \gamma$ protomer provides the docking surface for MMOR and MMOB. MMOB, which has no cofactors, consists of seven $\beta$ strands arranged in two $\beta$ sheets and three $a$ helices. MMOR consists of two mixed $\alpha \beta$ domains: an FAD- and NADH-binding domain provides electrons to a [2Fe-2S] ferredoxin domain for transfer to the MMOH active site. ${ }^{7,22}$ 


\section{Particulate MMO}

The first crystal structure of pMMO was that of the M. capsulatus (Bath) enzyme, determined in 2005 to $2.8 \AA$ resolution. ${ }^{23}$ Structures of pMMOs from Methylosinus trichosporium OB3b, Methylocystis species strain M, and Methylocystis species strain Rockwell have also been reported (Table 1). ${ }^{24-26}$ The pmoB, pmoA, and pmoC subunits are arranged as a $300 \mathrm{kDa} \alpha_{3} \beta_{3} \gamma_{3}$ trimer (Figure $2 \mathrm{~B}$ ), which is consistent with electron microscopic data. ${ }^{27}$ The pmoB subunit (42 kDa) consists of two cupredoxin-like domains linked by two transmembrane helices. The pmoA ( $24 \mathrm{kDa})$ and pmoC $(22 \mathrm{kDa})$ subunits are composed primarily of transmembrane helices. In three of the four pMMO crystal structures, an additional helix not connected to any of the pMMO subunits is observed and appears to interact closely with the pmoC subunit. ${ }^{24-26}$ In the Methylocystis sp. str. Rockwell pMMO structure, this interaction is mediated by a lipid molecule (Figure 3 ) ${ }^{26}$ Since pMMO is crystallized from the native organism, this yet to be identified helix is likely physiologically relevant.

\section{METAL CENTERS AND ACTIVE SITE STRUCTURE}

\section{Soluble MMO}

MMOH contains only one type of metal center, the diiron active site located in each a subunit in the $a_{2} \beta_{2} \gamma_{2}$ dimer. This diiron center is housed within a four-helix bundle of which surface-exposed helices $\mathrm{E}$ and $\mathrm{F}$ play key roles in modulating structural changes throughout the catalytic cycle. ${ }^{22} \mathrm{Fe} 1$ is coordinated by His147, Glu114, and a water molecule, and Fe2 is coordinated by His246, Glu243, and Glu209. ${ }^{20}$ The two iron ions are bridged by residue Glu144 and two hydroxides (Figure 4A). Upon reduction, the $\mathrm{Fe}-\mathrm{Fe}$ distance increases from $\sim 3.1 \AA$ to $\sim 3.3 \AA$, and Glu243 undergoes a carboxylate shift, replacing the bridging hydroxide ion as a ligand to the diiron center. This shift opens a site for reaction with dioxygen (Figure 4B). ${ }^{21,28}$ It is well established that the two iron ions are present as an antiferromagnetically coupled diiron(III) site in oxidized $\mathrm{MMOH}$ and a weakly ferromagnetically coupled diiron(II) center in reduced MMOH. ${ }^{29-32}$ A mixed valence form can also be generated, but does not play a role in the catalytic cycle. ${ }^{7}$

\section{Particulate MMO}

In contrast to $\mathrm{MMOH}$, several metal centers are observed in the structures of pMMO. All structures contain a copper binding site at the $\mathrm{N}$-terminus of the pmoB subunit with ligands His33, which is the amino terminal residue of pmoB, His137, and His139 (M. capsulatus (Bath) numbering) (Figure 5). Guided by extended X-ray absorption fine structure (EXAFS) data, ${ }^{33}$ this site was modeled as two copper ions with a $\mathrm{Cu}-\mathrm{Cu}$ distance of $\sim 2.5 \AA$ in the structures of M. capsulatus (Bath) ${ }^{23}$ and M. trichosporium $\mathrm{OB}_{3} \mathrm{~b}^{24} \mathrm{pMMO}$, and in one protomer of Methylocystis sp. str. M pMMO ${ }^{25}$ However, the moderate crystallographic resolution (2.6-3.9 $\AA$ ) precludes definitive assignment of the nuclearity. This site was modeled as monocopper in Methylocystis sp. str. Rockwell $\mathrm{pMMO}^{26}$ and in two protomers of Methylocystis sp. str. M pMMO.$^{25}$ Both of these pMMOs exhibit low copper binding stoichiometries once the enzyme is purified and concentrated. In the Methylocystis sp. str. Rockwell pMMO structure, a solvent molecule is modeled coordinated to the single copper ion (Figure 5) and is within hydrogen bonding distance of Glu31 (Glu35 using M. capsulatus 
(Bath) numbering). ${ }^{26} \mathrm{~A}$ monocopper site is also present at the equivalent location in the 1.8 $\AA$ resolution structure of the soluble domain of the amoB subunit from Nitrosocaldus yellowstonii AMO, indicating conservation of this site over the broad pMMO/AMO superfamily. However, in this structure, the copper ion is involved in a crystal lattice contact, and the $\mathrm{N}$-terminal histidine ligand is disordered. ${ }^{34}$ In the $M$. capsulatus (Bath) pmoB subunit, an additional copper ion is present at the interface of the two cupredoxin domains, coordinated by His 48 and His 72 (Figure 5). The His48 ligand is not conserved in other pMMO sequences, ${ }^{35}$ and the site is not observed in the other pMMO structures. ${ }^{24-26}$

Several lines of evidence suggest that the crystallographically modeled dicopper center is the active site of pMMO. First, the ligands to the dicopper center are conserved in almost all methanotroph pmoB sequences as well as in homologous subunits from all members of the pMMO/AMO superfamily. ${ }^{34}$ The only exceptions are a few pmoB sequences from methaneoxidizing Verrucomicrobia. ${ }^{36,37}$ These sequences are evolutionary distant, and it is possible that their extreme growth environments $\left(\mathrm{pH} 0.8-5,22-88^{\circ} \mathrm{C}\right)$ require a different type of active site. ${ }^{9}$ Second, metal loading of apo membrane-bound $\mathrm{pMMO}$ only results in methane oxidation after addition of 2-3 copper equivalents per $100 \mathrm{kDa} a \beta \gamma$ pMMO protomer, consistent with an active site requiring more than one copper ion. ${ }^{26,38}$ Third and most important, a recombinant soluble fragment of the $M$. capsulatus (Bath) pmoB subunit (spmoB, Figure 5) can oxidize methane to methanol in the presence of copper, and this activity is abolished upon mutagenesis of two or all three of the ligands to the dicopper site. ${ }^{38,39}$ Consistent with this model, mutagenesis of the ligand equivalent to His139 in a homologous Mycobacterium NBB4 hydrocarbon monooxygenase (HMO) that oxidizes C2C4 alkanes reduces activity significantly. However, in that enzyme, $20 \%$ residual activity is retained, ${ }^{40}$ perhaps due to copper binding by the other ligands, as has been observed for spmoB. ${ }^{39}$

Both $\mathrm{Cu}^{\mathrm{I}}$ and $\mathrm{Cu}^{\mathrm{II}}$ are routinely detected in pMMO by $\mathrm{X}$-ray absorption spectroscopy, ${ }^{33}$ and all samples of pMMO exhibit an electron paramagnetic resonance (EPR) spectroscopic signal attributable to a type $2 \mathrm{Cu}^{\mathrm{II}}$ site. ${ }^{39,41,42}$ Correlation of EPR signals with specific crystallographic copper sites in $M$. capsulatus (Bath) pMMO has been facilitated by comparative analysis of $\mathrm{pMMO}$ and the spmoB proteins. ${ }^{39} \mathrm{EPR}$ and metal analysis using pMMO and spmoB variants that disrupt the monocopper (H48N,H72A), dicopper (H33,137,139A), or both copper (H48N_H33,72,137,139A) sites indicate the presence of a valence localized, mixed valence $\mathrm{Cu}^{\mathrm{I}} \mathrm{Cu}^{\mathrm{II}}$ center at the dicopper site and $\mathrm{Cu}^{\mathrm{I}}$ ion at the monocopper site. The location of the $\mathrm{Cu}^{\mathrm{II}}$ is proposed to be valence scrambled between the two copper binding sites with one copper coordinated by His137 and His139, and one coordinated by His 33 and the $\mathrm{N}$-terminal amino group. No water or hydroxide ligands to the $\mathrm{Cu}^{\mathrm{II}}$ ion are detected.

An additional metal binding site is present in the pmoC subunit of pMMO. This site can bind zinc or copper, and the metal ion is coordinated by residues Asp156, His160, and His173 (M. capsulatus (Bath) numbering) (Figure 5). ${ }^{23-26}$ Recent metal binding studies using pMMOs from M. capsulatus (Bath) and Methylocystis sp. str. Rockwell suggest that zinc binding at this site partially inhibits activity, perhaps by interfering with proton transfer, and that this site is likely unoccupied by metal ions in vivo. ${ }^{26}$ Interestingly, a structure of 
Methylocystis sp. str. Rockwell pMMO soaked in zinc reveals a fourth ligand to this site, Glu201 (Glu 228 using M. capsulatus (Bath) numbering) (Figure 5), which derives from a loop region of pmoC that is disordered in all previous structures. This region spanning pmoC residues 200-223 (Methylocystis sp. str. Rockwell numbering) contains many strictly invariant residues, including Glu211, Phe213, His218, Phe221, and Val222 (Glu238, Phe240, His245, Phe248, and Val249 using M. capsulatus (Bath) numbering). The potential importance of this pmoC region is underscored by mutagenesis studies of the Mycobacterium NBB4 HMO in which individual mutations in the residues corresponding to ligands Asp156, His160, and His173 (M. capsulatus (Bath) numbering) completely abrogated hydrocarbon oxidation activity. ${ }^{40}$ Replacement of the residue equivalent to Asp166 (M. capsulatus (Bath) numbering) also abolished activity, which is interesting because this residue is located on a flexible loop that points away from the metal binding site in the pMMO structures.

\section{SUBSTRATE BINDING AND REACTIVITY}

\section{Soluble MMO}

In most studies, the activity of sMMO has been determined by measuring the epoxidation of propylene. This assay was preferred historically because the product, propylene oxide, is not further oxidized by methanotroph cells and extracts. ${ }^{43}$ For M. capsulatus (Bath) sMMO, the turnover number for methane is in the range of $0.2-1.0 \mathrm{~s}^{-1}$ at $45^{\circ} \mathrm{C}$ and that for propylene is $\sim 0.7 \mathrm{~s}^{-1}$ (Table 2). ${ }^{44,45}$ The $K_{\mathrm{m}}$ values for methane and propylene are 0.94 and $2 \mu \mathrm{M}$, respectively, and the $K_{\mathrm{m}}$ value for $\mathrm{O}_{2}$ is $\sim 16 \mu \mathrm{M}$ with both substrates. ${ }^{44}$ For $M$. trichosporium OB3b sMMO, turnover numbers of $3.7 \mathrm{~s}^{-1}$ and $4.4 \mathrm{~s}^{-1}$ at $30^{\circ} \mathrm{C}$ have been reported for methane and propylene, respectively, ${ }^{46}$ and the $K_{\mathrm{m}}$ for methane is $\sim 12 \mu \mathrm{M} .{ }^{47}$ The whole cell $M$. trichosporium OB3b sMMO turnover number is at least $3.5 \mathrm{~s}^{-1}$ (Table 2). ${ }^{46}$

sMMO can oxidize a wide range of hydrocarbons, including C1-C8 n-alkanes, alkenes, and larger substrates such as benzene, styrene, naphthalene, ethylbenzene, and cyclohexane. ${ }^{48-51}$ In addition, sMMO oxidizes various halogenated hydrocarbons, including pollutants such as trichloroethylene. ${ }^{10,52}$ Crystallographic data indicate that substrates and products can occupy a chain of hydrophobic cavities, denoted cavities $1-3$, in the a subunit of $\mathrm{MMOH}$ (Figure 6A). ${ }^{53}$ Cavities 2 and 3 are linked, but are only connected with cavity 1 , which is next to the diiron active site, when MMOB is bound to $\mathrm{MMOH} .{ }^{54,55} \mathrm{~A}$ number of crystal structures with bound xenon, halogenated alkanes, and product alcohols have been obtained (Table 1). The substrate analogues dibromomethane, iodoethane, and xenon bind in cavities 2 and $3 .{ }^{56}$ Along with methanol and ethanol, the product analogues 2-bromoethanol, 3chloropropanol, and 3-bromobutenol bind in cavities 1-3 and can bridge the diiron center, replacing a bound water molecule (Figure 6B). ${ }^{54,57}$ These structures are consistent with optical, resonance Raman, magnetic circular dichroism, electron nuclear double resonance (ENDOR), and EPR spectroscopic data showing that substrates and products can affect the diiron site. ${ }^{58-62}$ However, recent time-resolved resonance Raman data indicate that the product alcohol does not bind directly to the diiron center. ${ }^{63}$ Access to the active site cavity (cavity 1) from cavities 2 and 3 is mediated by conformational changes in two residues, 
Leu110 and Phe188, which form a gate ${ }^{53,54}$ The functional relevance of this chain of cavities to the catalytic cycle remains controversial, however. Finally, an $\sim 10 \AA$ long hydrophilic pathway called the pore region is present and may function in alcohol and water release as well as play a role in proton transfer. ${ }^{54,55,64}$

\section{Particulate MMO}

Because of difficulties isolating stable and active purified samples of pMMO, the enzyme kinetics have not been investigated thoroughly. Assays are further complicated by the use of different reductants, including NADH and duroquinol for isolated membranes, duroquinol for purified $\mathrm{pMMO},{ }^{8}$ and formate for whole cells. ${ }^{48}$ For isolated M. capsulatus (Bath) membranes, of which pMMO is the main component (such preparations are referred to as membrane-bound pMMO and can sometimes be crystallized upon solubilization without further purification ${ }^{25}$ ), methane oxidation activities are in the range of $25-130 \mathrm{nmol} \mathrm{min}{ }^{-1}$ $\mathrm{mg}^{-1}$, depending on the preparation and reductant. ${ }^{26}$ Assuming that these samples are $80 \%$ pMMO, a turnover number in the range of $3-16 \mathrm{~min}^{-1}$ can be estimated (Table 2). For propylene, membrane-bound pMMO activities are $16-123 \mathrm{nmol} \mathrm{min}^{-1} \mathrm{mg}^{-1},{ }^{12}, 65$ giving an estimated turnover number of $2-15 \mathrm{~min}^{-1}$. For purified M. capsulatus (Bath) pMMO, specific activities of $17-160 \mathrm{nmol} \mathrm{min}{ }^{-1} \mathrm{mg}^{-1}$ for propylene have been reported, ${ }^{10}$ corresponding to turnover numbers of $0.17-16 \mathrm{~min}^{-1}$. Lower activities of 2-23 $\mathrm{nmol} \mathrm{min}-1$ $\mathrm{mg}^{-1}$ have been obtained for membrane-bound pMMO samples from $M$. trichosporium OB3b, Methylocystis sp. str. M, and Methylocystis sp. str. Rockwell, with very little activity after solubilization and purification. ${ }^{9,}{ }^{26}$ The whole cell M. trichosporium OB3b pMMO $\mathrm{V}_{\max }$ is $82-300 \mathrm{nmol} \mathrm{min}^{-1} \mathrm{mg}^{-1}$ total protein (measured by methane consumption), ${ }^{66}$ which corresponds to a turnover number of $30-150 \mathrm{~min}^{-1}$, assuming $20 \%$ of the total protein is pMMO ${ }^{67}$ Similar $V_{\max }$ values were measured by propylene epoxidation for whole cells of $M$. capsulatus (Bath) pMMO. ${ }^{12,67,68}$ Thus, preserving pMMO activity upon removal from the membranes remains an important issue. Apparent pMMO $K_{\mathrm{m}}$ values for methane have been reported in the range of $1-62 \mu \mathrm{M} .{ }^{66,69,70}$ Notably, some methanotrophs, including Methylocystis sp. strain SC2, can produce a high affinity pMMO with a much lower apparent $K_{\mathrm{m}}$ for methane. ${ }^{70}$ The molecular basis for this enhanced methane affinity is not known.

pMMO has a much narrower substrate range than sMMO and can oxidize only C1-C5 nalkanes and terminal alkenes to 2-alcohols and 1,2-epoxides. ${ }^{48,71-73}$ Analysis of the pMMO structures reveals a cavity at the proposed dicopper active site as well as a second cavity extending to the zinc binding site. ${ }^{19,74}$ However, the functional relevance of these cavities remains unclear due to the moderate resolution of the pMMO structures and the lack of structures in the presence of substrates and products or analogues thereof. A hydrophobic pocket the size of pentane in the pmoA subunit has also been identified computationally ${ }^{75}$ but is not near any of crystallo-graphically observed metal binding sites. The narrow substrate specificity of pMMO and its ability to selectively orient substrates to produce (R)alcohols ${ }^{72,76}$ suggests that a fairly restricted cavity must be present at the active site. Sitedirected mutagenesis studies of the Mycobacterium NBB4 HMO suggest that residue Ala 151, which is equivalent to pmoC Asp166 in M. capsulatus (Bath) pMMO, is important for determining substrate specificity. ${ }^{40}$ This residue lies at the interface of pmoB and pmoC, 
about $8 \AA$ from the dicopper center, and could modulate the sizes of the aforementioned cavities. Notably, AMO has a much broader substrate specificity, ${ }^{6}$ but there are no crystal structures of AMO, and the molecular basis for this difference remains unclear.

\section{PROTEIN-PROTEIN INTERACTIONS}

\section{Soluble MMO}

MMOH interacts with MMOB and MMOR. MMOB is essential for efficient hydrocarbon oxidation by $\mathrm{MMOH}$. Binding of MMOB increases the reaction rate of reduced $\mathrm{MMOH}$ with $\mathrm{O}_{2}$ by 1000 -fold, ${ }^{77,78}$ lowers the redox potential of the diiron center,${ }^{79}$ changes the regioselectivity of substrate oxidation, ${ }^{80}$ and affects the structure of the diiron center. ${ }^{59,} 81,82$ The 2.9 A resolution structure of the M. capsulatus (Bath) MMOH-2MMOB complex reveals that MMOB binds to the canyon region at the dimer interface of $\mathrm{MMOH}$, leading to the ordering of the N-terminal 35 residues of MMOB, which are not observed in the NMR structures, ${ }^{83,84}$ into a ring-like fold (Figure 7A). ${ }^{55}$ MMOB binding also causes conformational changes in $\mathrm{MMOH}$ residue Phe188 of the a subunit, opening up a pathway from the surface to the active site. In addition, Thr213 of the MMOH a subunit rotates inward toward the active site, forming new hydrogen bonds with Glu240 and closing the hydrophilic pore (Figure 7B,C). This residue has been proposed to play a role in proton delivery. Finally, MMOB binding induces small changes in some of the ligands, including a shift of Glu243 to a coordination more similar to that in reduced MMOH. ${ }^{55}$

MMOR transfers two electrons from NADH one at a time to the diiron site in MMOH via its FAD and [2Fe-2S] cofactors. ${ }^{85,86}$ There is no crystal structure of the MMOH-MMOR complex, but NMR titrations indicate that residues 24-34 in a helix 1 and residues 67-69 in a helix 2 interact with MMOH. ${ }^{87}$ Chemical cross-linking studies have suggested that MMOR interacts with both the $\alpha^{88}$ and $\beta^{81}$ subunits of $\mathrm{MMOH}$, and recent work using hydrogen-deuterium exchange coupled to mass spectrometry (HDX-MS) and computational docking suggests that the ferredoxin domain of MMOR binds to MMOH at the same location where MMOB binds. At this binding site, the MMOR [2Fe-2S] cluster is positioned $14 \AA$ away from the diiron active site and does indeed interact with both subunits. Consistent with these findings, MMOB inhibits MMOR binding as well as electron transfer. ${ }^{89}$ However, it is also possible that MMOB inhibits MMOR binding by forming a complex with MMOR. ${ }^{81}$

Recent fluorescence anisotropy experiments suggest that MMOB has a higher affinity for $\mathrm{MMOH}$ in the reduced form $\left(K_{\mathrm{d}}=0.17 \mu \mathrm{M}\right)$ than in the oxidized form $\left(K_{\mathrm{d}}=0.55 \mu \mathrm{M}\right),{ }^{90}$ an observation that is difficult to reconcile with the lowered redox potential of $\mathrm{MMOH}$ in the presence of MMOB. ${ }^{79,} 91$ Double electron-electron resonance (DEER) spectroscopic data further suggest that the conformation of the N-terminal tail of MMOB is more rigid when $\mathrm{MMOH}$ is reduced. ${ }^{90}$ The key role of the MMOB N-terminus is underscored by data showing that mutants of MMOB disrupting the $\mathrm{N}$-terminus display significantly reduced activity. ${ }^{55,92}$ In one functional model, MMOR is proposed to replace MMOB, transfer electrons to reduce the active site, and then MMOB is proposed to rebind to the reduced form, displacing MMOR, and initiating $\mathrm{O}_{2}$ activation and methane oxidation. ${ }^{89} \mathrm{In}$ the 
absence of experimental evidence for MMOR displacing MMOB from the oxidized $\mathrm{MMOH}$, this scenario remains speculative.

\section{Particulate MMO}

Protein-protein interactions are not required for pMMO activity in vitro, but protein-protein complexes involving pMMO have been suggested. Besides the interaction with the mystery helix observed crystallographically (Figure 3), ${ }^{24-26}$ pMMO has been proposed to interact with the next enzyme in the methane oxidation metabolic pathway, methanol dehydrogenase (MDH). ${ }^{93} \mathrm{MDH}$ is a periplasmic enzyme that oxidizes methanol to formaldehyde and is composed of a $63 \mathrm{kDa}$ a subunit, which contains a pyrroloquinoline quinone (PQQ)/calcium ion cofactor, and a $8 \mathrm{kDa} \beta$ subunit arranged as an $\mathrm{a}_{2} \beta_{2}$ dimer. ${ }^{94,}{ }^{95}$ The $M$. capsulatus (Bath) MDH can also form higher order heterogeneous oligomers. ${ }^{95}$ A putative pMMOMDH super-complex was isolated, and its structure was determined to $16 \AA$ resolution by electron microscopy. This structure was interpreted as three $\alpha \beta \mathrm{MDH}$ monomers capping the periplasmic pmoB soluble domains of the pMMO $\alpha_{3} \beta_{3} \gamma_{3}$ trimer. ${ }^{96}$ This pMMO-MDH complex exhibited moderately higher propylene epoxidation activity than pMMO alone,${ }^{96,97}$ but its methane oxidation activity was not reported. Recent biolayer interferometry studies of MDH and pMMO from M. capsulatus (Bath) reveal a specific protein-protein interaction. ${ }^{95}$ An interaction was also detected between MDH and the spmoB recombinant protein, indicating that the periplasmic regions of pmoB are involved..$^{95}$ These data are consistent with reports that MDH is associated with the membranes in various methanotrophs. ${ }^{98-100}$ The observed complex is likely dynamic since a stable complex cannot be isolated by size exclusion chromatography, and its formation may depend on the presence of the membrane or other proteins. One proposal is that the lysine-rich $\beta$ subunit of MDH, of which the function is not known, interacts with pMMO and/or negatively charged phospholipid headgroups at the periplasmic membrane, ${ }^{95}$ thus associating with pMMO in a fashion that would be difficult to reconstitute in vitro. Such a model would not apply to methanotrophs that utilize a subset of MDH enzymes lacking the $\beta$ subunit, ${ }^{101}$ but these methanotrophs, which include the Verrucomicrobia, ${ }^{102}$ also have different types of membranes. ${ }^{36}$

A pMMO/MDH supercomplex would provide a direct pathway for methanol produced at the proposed dicopper active site in the pMMO pmoB subunit to the active site of MDH where it is oxidized to formaldehyde. In addition, such a complex could directly provide reducing equivalents to $\mathrm{pMMO}$ through the cytochrome $\mathrm{c}_{\mathrm{L}}$, the electron acceptor of MDH. ${ }^{96}, 97,103-105$ Another and perhaps more widely accepted electron source for pMMO involves ubiquinol generated by a type $2 \mathrm{NADH}$ :quinone oxidoreductase (NDH-2). ${ }^{12,106,107}$ In support of this pathway, NADH is an effective reductant for membrane-bound pMMO, but duroquinol is the only reductant that is effective after detergent solubilization. ${ }^{71,108}$ Duroquinol may mimic the function and redox potential of endogenous quinols, ${ }^{108}$ and it is known that methanotrophs produce a range of ubiquinones, but not menaquinone. ${ }^{109,110}$ Moreover, addition of NADH and NDH-2 to purified pMMO samples leads to a modest increase in propylene epoxidation activity. ${ }^{12} \mathrm{NDH}-2$ and pMMO can be copurified, ${ }^{12}$ but there is no evidence that they form a specific protein-protein complex. Finally, in M. capsulatus (Bath), a cytoplasmic hemerythrin protein increases the 
activity of pMMO, suggesting that hemerythrin facilitates oxygen delivery to pMMO. ${ }^{111}$ However, there is no evidence for a protein-protein interaction between pMMO and this hemerythrin.

\section{MECHANISM}

\section{Soluble MMO}

The details of how sMMO activates dioxygen have been probed extensively by single turnover kinetic studies, resulting in the identification of transient oxygen intermediates, the kinetic and spectroscopic properties of which are detailed elsewhere. ${ }^{14,19,112}$ First, the reduced diiron(II) $\mathrm{MMOH}$ reacts with $\mathrm{O}_{2}$ in the presence of 2 equiv of MMOB to form a species $\mathrm{O}$ in which $\mathrm{O}_{2}$ is bound, but not directly to the diiron cluster. ${ }^{77}$ Intermediate $\mathrm{O}$ is then converted to peroxo intermediates $\mathrm{P} *$ and $\mathrm{P}$. For M. capsulatus (Bath) MMOH, $\mathrm{P} *$ is observed to be a diiron(III) site that differs from the subsequent intermediate $\mathrm{P}$ only in ligand arrangement. ${ }^{113}$ However, recent studies of $M$. trichosporium OB3b MMOH utilizing a variant of MMOB that slows conversion of $\mathrm{P} *$ to $\mathrm{P}$ indicate that $\mathrm{P} *$ contains a diiron(II) site similar in structure to the diiron(II) site in reduced $\mathrm{MMOH}$. In this system, $\mathrm{P} *$ is proposed to form by displacement of the bridging $\mathrm{H}_{2} \mathrm{O}$ ligand by $\mathrm{O}_{2}$ without electron transfer from the diiron(II) center. ${ }^{114}$ Thus, it remains unclear whether the two intermediates denoted $\mathrm{P}^{*}$ are the same. The second peroxo intermediate, $\mathrm{P}$, is a diiron(III) species, and spectroscopic comparisons as well as computational work suggest that a $\mu$-1,2-peroxo bridge is likely. ${ }^{14,115}$ Formation of $\mathrm{P}$ is $\mathrm{pH}$-dependent and exhibits a kinetic solvent isotope effect in $\mathrm{D}_{2} \mathrm{O}$, indicating that proton transfer plays a role. ${ }^{113,116}$ It is also possible to bypass the requirement for MMOB and MMOR in these steps by reacting the oxidized $\mathrm{MMOH}$ with $\mathrm{H}_{2} \mathrm{O}_{2}$ as source of both oxygen and electrons. However, very high concentrations of $\mathrm{H}_{2} \mathrm{O}_{2}$ are required, with an apparent $K_{\mathrm{m}}$ value of $\sim 66 \mathrm{mM} .{ }^{117,118}$

Intermediate $\mathrm{P}$ is then converted to $\mathrm{Q}$ in a proton-dependent step ${ }^{113}, 116$ that results in $\mathrm{O}-\mathrm{O}$ bond breaking. Intermediate $\mathrm{Q}$ is the species that reacts with methane to break the $\mathrm{C}-\mathrm{H}$ bond. On the basis of Mössbauer spectroscopic data indicating the presence of two $\mathrm{Fe}^{\mathrm{IV}}$ ions in similar coordination environments and EXAFS data best fit with an $\mathrm{Fe}-\mathrm{Fe}$ distance of $2.46 \AA$, Q was proposed to adopt a di( $\mu$-oxo) diamond core structure. ${ }^{119,}{ }^{120}$ Difficulty reproducing this distance computationally ${ }^{121,122}$ combined with the observation that a model complex with an open core terminal $\mathrm{Fe}^{\mathrm{IV}}=\mathrm{O}$ unit can oxidize $\mathrm{C}-\mathrm{H}$ bonds rapidly, ${ }^{123}$ although not those in methane, suggested Q might have an alternative structure. However, a recent time-resolved resonance Raman study reveals a vibration from $\mathrm{Q}$ that best matches vibrations observed for the diamond core in model compounds. Additional experiments with mixed isotopes of $\mathrm{O}_{2}$ further indicate that $\mathrm{Q}$ forms via homolytic cleavage of the $\mathrm{O}-\mathrm{O}$ bond. ${ }^{63,124}$ Once $\mathrm{Q}$ is formed, there are several mechanistic possibilities for $\mathrm{C}-\mathrm{H}$ activation, including both concerted and radical or cationic processes. ${ }^{19} \mathrm{~A}$ range of approaches, such as the use of chiral alkane and radical clock substrates, the measurement of kinetic isotope effects, and computational analysis, have been used to investigate these options. ${ }^{125}$ After methane oxidation, $\mathrm{Q}$ is converted to the product complex $\mathrm{T}$, which is proposed to have a mono- $\mu$-oxo bridged structure. ${ }^{63}$ 


\section{Particulate MMO}

Mechanistic studies of pMMO are far behind those of sMMO, due to ongoing difficulties isolating highly active purified enzyme and uncertainty as to the atomic details of the active site (vide supra). ${ }^{9}$ Density functional theory (DFT) and quantum mechanics/molecular mechanics $(\mathrm{QM} / \mathrm{MM})$ studies suggest that a monocopper $\mathrm{Cu}^{\mathrm{III}}$-oxo species or a di $(\mu$ oxo) $\mathrm{Cu}^{\mathrm{II}} \mathrm{Cu}^{\mathrm{III}}$ species could oxidize methane and that formation of the dicopper species is more favorable. ${ }^{126}$ Calculations using a dicopper active site model suggest that either a $\mu$ $\eta^{1}: \eta^{2}$-peroxo $\mathrm{Cu}^{\mathrm{I}} \mathrm{Cu}^{\mathrm{II}}$ or $\mu-\eta^{2}: \eta^{2}$-peroxo $\mathrm{Cu}^{\mathrm{II}} \mathrm{Cu}^{\mathrm{II}}$ species is formed first and then is transformed into the more reactive $\mathrm{di}(\mu-\mathrm{oxo}) \mathrm{Cu}^{\mathrm{II}} \mathrm{Cu}^{\mathrm{III}}$ species after $\mathrm{O}-\mathrm{O}$ bond cleavage. ${ }^{126,127}$ In later studies, a ( $\mu$-oxo) $\left(\mu\right.$-hydroxo) $\mathrm{Cu}^{\mathrm{II}} \mathrm{Cu}^{\mathrm{III}}$ center was proposed to be the active species and was calculated to be more reactive toward methane than a di $(\mu-$ oxo) $\mathrm{Cu}^{\mathrm{II}} \mathrm{Cu}^{\mathrm{III}}$ species. Formation of this ( $\mu$-oxo)( $\mu$-hydroxo) $\mathrm{Cu}^{\mathrm{II}} \mathrm{Cu}^{\mathrm{III}}$ species is proposed to be facilitated by proton transfer involving residues Tyr374 and Glu35 (M. capsulatus (Bath) numbering, Tyr374 is not structurally conserved in other pMMOs) in the second coordination sphere of the dicopper center. ${ }^{128}$ It is important to note that these intermediates have been calculated based on the moderate resolution crystal structures of pMMO and have not been detected experimentally. Related to these ideas are recent studies of the zeolite $\mathrm{Cu}$ ZSM-5, which can oxidize methane to methanol. Spectroscopic studies and DFT calculations show that the zeolite active species is a mono $(\mu-\mathrm{oxo}) \mathrm{Cu}^{\mathrm{II}} \mathrm{Cu}{ }^{\mathrm{II}}$ core formed from a $\mu-\eta^{2}: \eta^{2}$-peroxoCu ${ }^{\mathrm{II}} \mathrm{Cu}^{\mathrm{II}}$ intermediate. ${ }^{129,130}$ Although pMMO and the zeolite are fundamentally different, this work does suggest that it may be feasible to oxidize methane in an enzyme with a dicopper site.

One putative oxygen intermediate has been detected experimentally for pMMO. When reduced pMMO is reacted with $\mathrm{H}_{2} \mathrm{O}_{2}$ or reduced spmoB is reacted with $\mathrm{O}_{2}$ or $\mathrm{H}_{2} \mathrm{O}_{2}$, a new species with an absorbance feature at $345 \mathrm{~nm}$ is formed. ${ }^{131}$ The energy and intensity of this feature are consistent with a $\mu-\eta^{2}: \eta^{2}$-peroxo $\mathrm{Cu}^{\mathrm{II}} \mathrm{Cu}^{\mathrm{II}}$ species like those formed in oxyhemocyanin and oxytyrosinase, ${ }^{132}$ a met $\mathrm{Cu}^{\mathrm{II}} \mathrm{Cu}^{\mathrm{II}}$ species like that in methemocyanin, ${ }^{133}, 134$ or a hydroxo-bridged $\mathrm{Cu}^{\mathrm{II}} \mathrm{Cu}^{\mathrm{II}}$ center like that in the type 3 copper centers of multicopper oxidases. ${ }^{135}$ Because of the instability of spmoB and heme contaminants present in pMMO, further studies of this species by resonance Raman spectroscopy have not been conducted. Importantly, this intermediate does not form in variants of spmoB in which the ligands to the dicopper center have been mutated, consistent with $\mathrm{O}_{2}$ binding at the proposed active site. In addition, this species disappears in the presence of methane, ${ }^{131}$ and some methanol product is detected, indicating that it may be a relevant intermediate during methane oxidation. The identity of the actual species that reacts with methane, the pMMO equivalent to $\mathrm{Q}$, remains unclear. Several studies using chiral alkanes suggest that $\mathrm{C}-\mathrm{H}$ bond activation by this unknown species proceeds via a concerted, nonradical mechanism. ${ }^{136}$

\section{CONCLUSIONS}

The two methane-oxidizing enzymes in nature, sMMO and pMMO, are completely different. The sMMO hydroxylase component, $\mathrm{MMOH}$, is a soluble $\alpha_{2} \beta_{2} \gamma_{2}$ dimer, whereas pMMO is an $\alpha_{3} \beta_{3} \gamma_{3}$ trimer with both membrane-bound and periplasmic regions. The active 
site of sMMO is a well-characterized diiron center, but the atomic structure of the pMMO copper active site remains unclear. Similarly, the structural basis for substrate and product access to the sMMO active site has been partially elucidated but is not well-defined for pMMO. Both MMOs oxidize a range of hydrocarbon substrates, but pMMO has a narrower substrate specificity. sMMO exhibits higher turnover numbers than pMMO both in cells and in isolated enzyme preparations, but neither enzyme achieves levels desirable for biological gas-to-liquid conversion processes. The delivery of electrons to the sMMO active site in $\mathrm{MMOH}$ and the roles of MMOB and MMOR are reasonably well understood on the molecular level, although some aspects remain controversial. By contrast, the source of electrons for $\mathrm{pMMO}$ is still under debate, and possible protein interaction partners such as MDH require further investigation. The catalytic cycle of sMMO has been mapped out, and the intermediate that breaks the methane $\mathrm{C}-\mathrm{H}$ bond, $\mathrm{Q}$, has been characterized. Although mechanistic possibilities for pMMO have been considered, its mechanism cannot be further elucidated until lingering questions about the active site are resolved. Despite all these differences, the two systems share the unique ability to oxidize methane, and it is remarkable that nature has evolved two distinct large enzyme complexes for oxidation of a small gaseous substrate. Further study of how each MMO orchestrates the delivery of methane, oxygen, protons, and electrons to the active site, and how the $\mathrm{O}-\mathrm{O}$ and $\mathrm{C}-\mathrm{H}$ bonds are broken is essential to understanding these enzymes, their roles in the environment, and their potential biotechnological applications.

\section{Acknowledgments}

Funding

Our work on biological methane oxidation is supported by National Institutes of Health Grant GM070473 and Advanced Research Projects Agency - Energy Grant DE-AR0000435.

\section{ABBREVIATIONS}

$\begin{array}{ll}\text { AMO } & \text { ammonia monooxygenase } \\ \text { ENDOR } & \text { electron nuclear double resonance } \\ \text { EPR } & \text { electron paramagnetic resonance } \\ \text { EXAFS } & \text { X-ray absorption fine structure } \\ \text { HMO } & \text { hydrocarbon monooxygenase } \\ \text { MDH } & \text { methanol dehydrogenase } \\ \text { MMO } & \text { methane monooxygenase } \\ \text { MMOB } & \text { sMMO regulatory protein } \\ \text { MMOR } & \text { sMMO reductase } \\ \text { MMOH } & \text { sMMO hydroxylase }\end{array}$

NDH-2 type 2 NADH:quinone oxidoreductase 
pMMO particulate methane monooxygenase

sMMO soluble methane monooxygenase

spmoB soluble fragment of the pMMO pmoB subunit

\section{REFERENCES}

1. Blanksby SJ, Ellison GB. Bond dissociation energies of organic molecules. Acc. Chem. Res. 2003; 36:255-263. [PubMed: 12693923]

2. Semrau JD. Bioremediation via methanotrophy: overview of recent findings and suggestions for future research. Front. Microbiol. 2011; 2:209. [PubMed: 22016748]

3. Haynes CA, Gonzalez R. Rethinking biological activation of methane and conversion to liquid fuels. Nat. Chem. Biol. 2014; 10:331-339. [PubMed: 24743257]

4. Que L, Tolman WB. Biologically inspired oxidation catalysis. Nature. 2008; 455:333-340. [PubMed: 18800132]

5. Austin RN, Groves JT. Alkane-oxidizing metalloenzymes in the carbon cycle. Metallomics. 2011; 3:775-787. [PubMed: 21743926]

6. Hooper AB, Vannelli T, Bergmann DJ, Arciero DM. Enzymology of the oxidation of ammonia to nitrite by bacteria. Antonie Van Leeuwenhoek. 1997; 71:59-67. [PubMed: 9049018]

7. Merkx M, Kopp DA, Sazinsky MH, Blazyk JL, Müller J, Lippard SJ. Dioxygen activation and methane hydroxylation by soluble methane monooxygenase: a tale of two irons and three proteins. Angew. Chem., Int. Ed. 2001; 40:2782-2807.

8. Lieberman RL, Rosenzweig AC. Biological methane oxidation: regulation, biochemistry, and active site structure of particulate methane monooxygenase. Crit. Rev. Biochem. Mol. Biol. 2004; 39:147164. [PubMed: 15596549]

9. Culpepper MA, Rosenzweig AC. Architecture and active site of particulate methane monooxygenase. Crit. Rev. Biochem. Mol. Biol. 2012; 47:483-492. [PubMed: 22725967]

10. Semrau JD, Dispirito AA, Yoon S. Methanotrophs and copper. FEMS Microbiol. Lett. 2010; 34:496-531.

11. Stanley SH, Prior SD, Leak DJ, Dalton H. Copper stress underlies the fundamental change in intracellular location of methane monooxygenase in methane oxidizing organisms: studies in batch and continuous cultures. Biotechnol. Lett. 1983; 5:487-492.

12. Choi DW, Kunz RC, Boyd ES, Semrau JD, Antholine WE, Han JI, Zahn JA, Boyd JM, de la Mora AM, DiSpirito AA. The membrane-associated methane monooxygenase pMMO and pMMONADH:quinone oxidoreductase complex from Methylococcus capsulatus Bath. J. Bacteriol. 2003; 185:5755-5764. [PubMed: 13129946]

13. Prior SD, Dalton $\mathrm{H}$. The effect of copper ions on membrane content and methane monooxygenase activity in methanol-grown cells of Methylococcus capsulatus (Bath). J. Gen. Microbiol. 1985; 131:155-163.

14. Tinberg CE, Lippard SJ. Dioxygen activation in soluble methane monooxygenase. Acc. Chem. Res. 2011; 44:280-288. [PubMed: 21391602]

15. Kenney GE, Rosenzweig AC. Chemistry and biology of the copper chelator methanobactin. ACS Chem. Biol. 2012; 7:260-268. [PubMed: 22126187]

16. Semrau JD, Jagadevan S, DiSpirito AA, Khalifa A, Scanlan J, Bergman BH, Freemeier BC, Baral BS, Bandow NL, Vorobev A, Haft DH, Vuilleumier S, Murrell JC. Methanobactin and MmoD work in concert to act as the 'copper-switch' in methanotrophs. Environ. Microbiol. 2013; 15:3077-3086. [PubMed: 23682956]

17. Scanlan J, Dumont MG, Murrell JC. Involvement of MmoR and MmoG in the transcriptional activation of soluble methane monooxygenase genes in Methylosinus trichosporium OB3b. FEMS Microbiol. Lett. 2009; 301:181-187. [PubMed: 19878324]

18. Csáki R, Bodrossy L, Klem J, Murrell JC, Kovács KL. Genes involved in the copper-dependent regulation of soluble methane monooxygenase of Methylococcus capsulatus (Bath): cloning, sequencing and mutational analysis. Microbiology. 2003; 149:1785-1795. [PubMed: 12855730] 
19. Sazinsky MH, Lippard SJ. Methane monooxygenase: functionalizing methane at iron and copper. Met. Ions Life Sci. 2015; 15:205-256. [PubMed: 25707469]

20. Rosenzweig AC, Frederick CA, Lippard SJ, Nordlund P. Crystal structure of a bacterial non-haem iron hydroxylase that catalyses the biological oxidation of methane. Nature. 1993; 366:537-543. [PubMed: 8255292]

21. Rosenzweig AC, Nordlund P, Takahara PM, Frederick CA, Lippard SJ. Geometry of the soluble methane monooxygenase catalytic diiron center in two oxidation states. Chem. Biol. 1995; 2:409418.

22. Sazinsky MH, Lippard SJ. Correlating structure with function in bacterial multicomponent monooxygenases and related diiron proteins. Acc. Chem. Res. 2006; 39:558-566. [PubMed: 16906752]

23. Lieberman RL, Rosenzweig AC. Crystal structure of a membrane-bound metalloenzyme that catalyses the biological oxidation of methane. Nature. 2005; 434:177-182. [PubMed: 15674245]

24. Hakemian AS, Kondapalli KC, Telser J, Hoffman BM, Stemmler TL, Rosenzweig AC. The metal centers of particulate methane monooxygenase from Methylosinus trichosporium OB3b. Biochemistry. 2008; 47:6793-6801. [PubMed: 18540635]

25. Smith SM, Rawat S, Telser J, Hoffman BM, Stemmler TL, Rosenzweig AC. Crystal structure and characterization of particulate methane monooxygenase from Methylocystis species strain M. Biochemistry. 2011; 50:10231-10240. [PubMed: 22013879]

26. Sirajuddin S, Barupala D, Helling S, Marcus K, Stemmler TL, Rosenzweig AC. Effects of zinc on particulate methane monooxygenase activity and structure. J. Biol. Chem. 2014; 289:2178221794. [PubMed: 24942740]

27. Kitmitto A, Myronova N, Basu P, Dalton H. Characterization and structural analysis of an active particulate methane monooxygenase trimer from Methylococcus capsulatus (Bath). Biochemistry. 2005; 44:10954-10965. [PubMed: 16101279]

28. Whittington DA, Lippard SJ. Crystal structures of soluble methane monooxygenase hydroxylase from Methylococcus capsulatus (Bath) demonstrating geometrical variability at the dinuclear iron active site. J. Am. Chem. Soc. 2001; 123:827-838. [PubMed: 11456616]

29. Fox BG, Surerus KK, Münck E, Lipscomb JD. Evidence for a $\mu$-oxo-bridged binuclear iron cluster in the hydroxylase component of methane monooxygenase. J. Biol. Chem. 1988; 263:1055310556. [PubMed: 2839495]

30. Hendrich MP, Münck E, Fox BG, Lipscomb JD. Integer-spin EPR studies of the fully reduced methane monooxygenase hydroxylase component. J. Am. Chem. Soc. 1990; 112:5861-5865.

31. DeWitt JG, Bentsen JG, Rosenzweig AC, Hedman B, Green J, Pilkington S, Papaefthymiou GC, Dalton H, Hodgson KO, Lippard SJ. X-ray absorption, Mössbauer, and EPR studies of the dinuclear iron center in the hydroxylase component of methane monooxygenase. J. Am. Chem. Soc. 1991; 113:9219-9235.

32. Fox BG, Hendrich MP, Surerus KK, Andersson KK, Froland WA, Lipscomb JD, Münck E. Mössbauer, EPR, and ENDOR studies of the hydroxylase and reductase components of methane monooxygenase from Methylosinus trichosporium OB3b. J. Am. Chem. Soc. 1993; 115:3688 3701.

33. Lieberman RL, Kondapalli KC, Shrestha DB, Hakemian AS, Smith SM, Telser J, Kuzelka J, Gupta R, Borovik AS, Lippard SJ, Hoffman BM, Rosenzweig AC, Stemmler TL. Characterization of the particulate methane monooxygenase metal centers in multiple redox states by X-ray absorption spectroscopy. Inorg. Chem. 2006; 45:8372-8381. [PubMed: 16999437]

34. Lawton TJ, Ham J, Sun T, Rosenzweig AC. Structural conservation of the B subunit in the ammonia monooxygenase/particulate methane monooxygenase superfamily. Proteins. 2014; 82:2263-2267. [PubMed: 24523098]

35. Hakemian AS, Rosenzweig AC. The biochemistry of methane oxidation. Annu. Rev. Biochem. 2007; 76:223-241. [PubMed: 17328677]

36. Op den Camp HJ, Islam T, Stott MB, Harhangi HR, Hynes A, Schouten S, Jetten MSM, Birkeland N-K, Pol A, Dunfield PF. Environmental, genomic and taxonomic perspectives on methanotrophic Verrucomicrobia. Environ. Microbiol. Rep. 2009; 1:293-306. [PubMed: 23765882] 
37. Sharp CE, Smirnova AV, Graham JM, Stott MB, Khadka R, Moore TR, Grasby SE, Strack M, Dunfield PF. Distribution and diversity of Verrucomicrobia methanotrophs in geothermal and acidic environments. Environ. Microbiol. 2014; 16:1867-1878. [PubMed: 24650084]

38. Balasubramanian R, Smith SM, Rawat S, Stemmler TL, Rosenzweig AC. Oxidation of methane by a biological dicopper centre. Nature. 2010; 465:115-119. [PubMed: 20410881]

39. Culpepper MA, Cutsail GE 3rd, Gunderson WA, Hoffman BM, Rosenzweig AC. Identification of the valence and coordination environment of the particulate methane monooxygenase copper centers by advanced EPR characterization. J. Am. Chem. Soc. 2014; 136:11767-11775. [PubMed: 25059917]

40. Liew EF, Tong DC, Coleman NV, Holmes AJ. Mutagenesis of the hydrocarbon monooxygenase indicates a metal centre in subunit-C, and not subunit-B, is essential for copper-containing membrane monooxygenase activity. Microbiol. 2014; 160:1267-1277.

41. Rosenzweig AC. The metal centres of particulate methane monooxygenase. Biochem. Soc. Trans. 2008; 36:1134-1137. [PubMed: 19021511]

42. Chan SI, Chen KH-C, Yu SS-F, Chen C-L, Kuo SS-J. Toward delineating the structure and function of the particulate methane monooxygenase from methanotrophic bacteria. Biochemistry. 2004; 43:4421-4430. [PubMed: 15078087]

43. Colby J, Dalton H. Resolution of the methane monooxygenase of Methylococcus capsulatus (Bath) into three components. Biochem. J. 1978; 171:461-468. [PubMed: 418777]

44. Green J, Dalton H. Steady-state kinetic analysis of soluble methane monooxygenase from Methylococcus capsulatus (Bath). Biochem. J. 1986; 236:155-162. [PubMed: 3098230]

45. Gassner GT, Lippard SJ. Component interactions in the soluble methane monooxygenase system from Methylococcus capsulatus (Bath). Biochemistry. 1999; 38:12768-12785. [PubMed: 10504247]

46. Fox BG, Froland WA, Jollie DR, Lipscomb JD. Methane Monooxygenase from Methylosinus trichosporium OB3b. Methods Enzymol. 1990; 188:191-202. [PubMed: 2280705]

47. Nesheim JC, Lipscomb JD. Large kinetic isotope effects in methane oxidation catalyzed by methane monooxygenase - evidence for $\mathrm{C}-\mathrm{H}$ bond cleavage in a reaction cycle intermediate. Biochemistry. 1996; 35:10240-10247. [PubMed: 8756490]

48. Burrows KJ, Cornish A, Scott D, Higgins IJ. Substrate specificities of the soluble and particulate methane monooxygenases of Methylosinus trichosporium OB3b. J. Gen. Microbiol. 1984; 130:327-3333.

49. Colby J, Stirling DI, Dalton H. The soluble methane monooxygenase of Methylococcus capsulatus (Bath). Its ability to oxygenate n-alkanes, ethers, and alicyclic, aromatic and heterocyclic compounds. Biochem. J. 1977; 165:395-402. [PubMed: 411486]

50. Green J, Dalton H. Substrate specificity of soluble methane monooxygenase. J. Biol. Chem. 1989; 264:17698-17703. [PubMed: 2808342]

51. Brusseau GA, Tsien H-C, Hanson RS, Wackett LP. Optimization of trichloroethylene oxidation by methanotrophs and the use of a colorimetric assay to detect soluble methane monooxygenase activity. Biodegradation. 1990; 1:19-29. [PubMed: 1368139]

52. Fox BG, Borneman JG, Wackett LP, Lipscomb JD. Haloalkene oxidation by the soluble methane monooxygenase from Methylosinus trichosporium OB3b: mechanistic and environmental implications. Biochemistry. 1990; 29:6419-6427. [PubMed: 2207083]

53. Rosenzweig AC, Brandstetter H, Whittington DA, Nordlund P, Lippard SJ, Frederick CA. Crystal structure of the methane monooxygenase hydroxylase from Methylococcus capsulatus (Bath) at 1.7 A resolution: implications for substrate gating and component interactions. Proteins. 1997; 29:141-152. [PubMed: 9329079]

54. Sazinsky MH, Lippard SJ. Product bound structures of the soluble methane monooxygenase hydroxylase from Methylococcus capsulatus (Bath): protein motion in the a-subunit. J. Am. Chem. Soc. 2005; 127:5814-5825. [PubMed: 15839679]

55. Lee SJ, McCormick MS, Lippard SJ, Cho U-S. Control of substrate access to the active site in methane monooxygenase. Nature. 2013; 494:380-384. [PubMed: 23395959] 
56. Whittington DA, Rosenzweig AC, Frederick CA, Lippard SJ. Xenon and halogenated alkanes track putative substrate binding cavities in the soluble methane monooxygenase hydroxylase. Biochemistry. 2001; 40:3476-3482. [PubMed: 11297413]

57. Whittington DA, Sazinsky MH, Lippard SJ. X-ray crystal structure of alcohol products bound at the active site of soluble methane monooxygenase. J. Am. Chem. Soc. 2001; 123:1794-1795. [PubMed: 11456795]

58. Andersson KK, Elgren TEL, Que J, Lipscomb JD. Accessibility to the active site of methane monooxygenase: the first demonstration of exogenous ligand binding to the diiron center. J. Am. Chem. Soc. 1992; 114:8711-8713.

59. Pulver SC, Froland WA, Lipscomb JD, Solomon EI. Ligand field circular dichroism and magnetic circular dichroism studies of component B and substrate binding to the hydroxylase component of methane monooxygenase. J. Am. Chem. Soc. 1997; 119:387-395.

60. DeRose VJ, Liu KE, Lippard SJ, Hoffman BM. Investigation of the dinuclear Fe center of methane monooxygenase by advanced paramagnetic resonance techniques: on the geometry of DMSO binding. J. Am. Chem. Soc. 1996; 118:121-134.

61. Hendrich MP, Fox BG, Andersson KK, Debrunner PG, Lipscomb JD. Ligation of the diiron site of the hydroxylase component of methane monooxygenase. J. Biol. Chem. 1992; 267:261-269. [PubMed: 1309736]

62. Smoukov SK, Kopp DA, Valentine AM, Davydov R, Lippard SJ, Hoffman BM. Product binding to the diiron(III) and mixed-valence diiron centers of methane monooxygenase hydroxylase studied by ${ }^{1,2} \mathrm{H}$ and ${ }^{19} \mathrm{~F}$ ENDOR spectroscopy. J. Am. Chem. Soc. 2002; 124:2657-2663. [PubMed: 11890816]

63. Banerjee R, Proshlyakov Y, Lipscomb JD, Proshlyakov DA. Structure of the key species in the enzymatic oxidation of methane to methanol. Nature. 2015; 518:431-434. [PubMed: 25607364]

64. Davydov R, Valentine AM, Komar-Panicucci S, Hoffman BM, Lippard SJ. An EPR study of the dinuclear iron site in the soluble methane monooxygenase from Methylococcus capsulatus (Bath) reduced by one electron at $77 \mathrm{~K}$ : the effects of component interactions and the binding of small molecules to the diiron(III) center. Biochemistry. 1999; 38:4188-4197. [PubMed: 10194335]

65. Lieberman RL, Shrestha DB, Doan PE, Hoffman BM, Stemmler TL, Rosenzweig AC. Purified particulate methane monooxygenase from Methylococcus capsulatus (Bath) is a dimer with both mononuclear copper and a copper-containing cluster. Proc. Natl. Acad. Sci. U.S.A. 2003; 100:3820-3825. [PubMed: 12634423]

66. Lontoh S, Semrau JD. Methane and trichloroethylene degradation by Methylosinus trichosporium OB3b expressing particulate methane monooxygenase. Appl. Environ. Microbiol. 1998; 64:11061114. [PubMed: 16349516]

67. Martinho M, Choi DW, DiSpirito AA, Antholine WE, Semrau JD, Münck E. Mössbauer studies of the membrane-associated methane monooxygenase from Methylococcus capsulatus Bath: evidence for a diiron center. J. Am. Chem. Soc. 2007; 129:15783-15785. [PubMed: 18052283]

68. Zahn JA, DiSpirito AA. Membrane-associated methane monooxygenase from Methylococcus capsulatus (Bath). J. Bacteriol. 1996; 178:1018-1029. [PubMed: 8576034]

69. Trotsenko, YA., Murrell, JC. Metabolic aspects of aerobic obligate methanotrophy. In: Laskin, AL., Sariaslani, S., editors. Advances in Applied Microbiology. Vol. 63. San Diego: Elsevier Academic Press Inc; 2008. p. 183-229.

70. Baani M, Liesack W. Two isozymes of particulate methane monooxygenase with different methane oxidation kinetics are found in Methylocystis sp strain SC2. Proc. Natl. Acad. Sci. U. S. A. 2008; 105:10203-10208. [PubMed: 18632585]

71. Smith DDS, Dalton H. Solubilisation of methane monooxygenase from Methylococcus capsulatus (Bath). Eur. J. Biochem. 1989; 182:667-671. [PubMed: 2502395]

72. Miyaji A, Miyoshi T, Motokura K, Baba T. The substrate binding cavity of particulate methane monooxygenase from Methylosinus trichosporium OB3b expresses high enantioselectivity for nbutane and n-pentane oxidation to 2-alcohol. Biotechnol. Lett. 2011; 33:2241-2246. [PubMed: 21744144] 
73. Jiang H, Chen Y, Jiang PX, Zhang C, Smith TJ, Murrell JC, Xing XH. Methanotrophs: Multifunctional bacteria with promising applications in environmental bioengineering. Biochem. Eng. J. 2010; 49:277-288.

74. Balasubramanian R, Rosenzweig AC. Structural and mechanistic insights into methane oxidation by particulate methane monooxygenase. Acc. Chem. Res. 2007; 40:573-580. [PubMed: 17444606]

75. Ng K-Y, Tu L-C, Wang Y-S, Chan SI, Yu SSF. Probing the hydrophobic pocket of the active site in the particulate methane monooxygenase (pMMO) from Methylococcus capsulatus (Bath) by variable stereoselective alkane hydroxylation and olefin epoxidation. ChemBioChem. 2008; 9:1116-1123. [PubMed: 18383583]

76. Elliott SJ, Zhu M, Tso L, Nguyen H-H, Yip JH-K, Chan SI. Regio- and stereoselectivity of particulate methane monooxygenase from Methylococcus capsulatus (Bath). J. Am. Chem. Soc. 1997; 119:9949-9955.

77. Liu Y, Nesheim JC, Lee SK, Lipscomb JD. Gating effects of component B on oxygen activation by the methane monooxygenase hydroxylase component. J. Biol. Chem. 1995; 270:24662-24665. [PubMed: 7559577]

78. Liu KE, Valentine AM, Wang D, Huynh BH, Edmondson DE, Salifoglou A, Lippard SJ. Kinetic and spectroscopic characterization of intermediates and component interactions in reactions of methane monooxygenase from Methylococcus capsulatus (Bath). J. Am. Chem. Soc. 1995; 117:10174-10185.

79. Paulsen KE, Liu Y, Fox BG, Lipscomb JD, Münck E, Stankovich MT. Oxidation-reduction potentials of the methane monooxygenase hydroxylase component from Methylosinus trichosporium OB3b. Biochemistry. 1994; 33:713-722. [PubMed: 8292599]

80. Froland WA, Andersson KK, Lee S-K, Lie Y, Lipscomb JD. Methane monooxygenase component $\mathrm{B}$ and reductase alter the regioselectivity of the hydroxylase component-catalyzed reaction. J. Biol. Chem. 1992; 267:17588-17597. [PubMed: 1325441]

81. Fox BG, Liu Y, Dege JE, Lipscomb JD. Complex formation between the protein components of methane monooxygenase from Methylosinus trichosporium OB3b. J. Biol. Chem. 1991; 266:540550. [PubMed: 1845980]

82. Mitić N, Schwartz JK, Brazeau BJ, Lipscomb JD, Solomon EI. CD and MCD studies of the effects of component $\mathrm{B}$ variant binding on the biferrous active site of methane monooxygenase. Biochemistry. 2008; 47:8386-8397. [PubMed: 18627173]

83. Walters KJ, Gassner GT, Lippard SJ, Wagner G. Structure of the soluble methane monooxygenase regulatory protein B. Proc. Natl. Acad. Sci. U. S. A. 1999; 96:7877-7882. [PubMed: 10393915]

84. Chang SL, Wallar BJ, Lipscomb JD, Mayo KH. Solution structure of component B from methane monooxygenase derived through heteronuclear NMR and molecular modeling. Biochemistry. 1999; 38:5799-5812. [PubMed: 10231531]

85. Lund J, Woodland MP, Dalton H. Electron transfer reactions in the soluble methane monooxygenase of Methylococcus capsulatus (Bath). Eur. J. Biochem. 1985; 147:297-305. [PubMed: 3918864]

86. Blazyk JL, Lippard SJ. Expression and characterization of ferredoxin and flavin adenine dinucleotide binding domains of the reductase component of soluble methane monooxygenase from Methylococcus capsulatus (Bath). Biochemistry. 2002; 41:15780-15794. [PubMed: 12501207]

87. Müller J, Lugovskoy AA, Wagner G, Lippard SJ. NMR structure of the [2Fe-2S] ferredoxin domain from soluble methane monooxygenase reductase and interaction with its hydroxylase. Biochemistry. 2002; 41:42-51. [PubMed: 11772001]

88. Kopp DA, Berg EA, Costello CE, Lippard SJ. Structural features of covalently cross-linked hydroxylase and reductase proteins of soluble methane monooxygenase as revealed by mass spectrometric analysis. J. Biol. Chem. 2003; 278:20939-20945. [PubMed: 12660237]

89. Wang WX, Iacob RE, Luoh RP, Engen JR, Lippard SJ. Electron transfer control in soluble methane monooxygenase. J. Am. Chem. Soc. 2014; 136:9754-9762. [PubMed: 24937475] 
90. Wang WX, Lippard SJ. Diiron oxidation state control of substrate access to the active site of soluble methane monooxygenase mediated by the regulatory component. J. Am. Chem. Soc. 2014; 136:2244-2247. [PubMed: 24476336]

91. Liu KE, Lippard SJ. Redox properties of the hydroxylase component of methane monooxygenase from Methylococcus capsulatus (Bath). J. Biol. Chem. 1991; 266(12836-12839):24859.

92. Chang SL, Wallar BJ, Lipscomb JD, Mayo KH. Residues in Methylosinus trichosporium OB3b methane monooxygenase component B involved in molecular interactions with reduced- and oxidized-hydroxylase component: A role for the N-terminus. Biochemistry. 2001; 40:9539-9551. [PubMed: 11583153]

93. Anthony C, Williams P. The structure and mechanism of methanol dehydrogenase. Biochim. Biophys. Acta. 2003; 1647:18-23. [PubMed: 12686102]

94. Gvozdev AR, Tukhvatullin IA, Gvozdev RI. Quinone-dependent alcohol dehydrogenases and FAD-dependent alcohol oxidases. Biochemistry (Moscow). 2012; 77:843-856. [PubMed: 22860906]

95. Culpepper MA, Rosenzweig AC. Structure and protein-protein interactions of methanol dehydrogenase from Methylococcus capsulatus (Bath). Biochemistry. 2014; 53:6211-6219. [PubMed: 25185034]

96. Myronova N, Kitmitto A, Collins RF, Miyaji A, Dalton H. Three-dimensional structure determination of a protein supercomplex that oxidizes methane to formaldehyde in Methylococcus capsulatus (Bath). Biochemistry. 2006; 45:11905-11914. [PubMed: 17002291]

97. Basu P, Katterle B, Andersson KK, Dalton H. The membrane-associated form of methane monooxygenase from Methylococcus capsulatus (Bath) is a copper/iron protein. Biochem. J. 2003; 369:417-427. [PubMed: 12379148]

98. Wadzinski AM, Ribbons DW. Oxidation of $\mathrm{C} 1$ compounds by particulate fractions from Methylococcus capsulatus: properties of methanol oxidase and methanol dehydrogenase. J. Bacteriol. 1975; 122:1364-1374. [PubMed: 238947]

99. Fassel TA, Buchholz LA, Collins MLP, Remsen CC. Localization of methanol dehydrogenase in two strains of methylotrophic bacteria detected by immunogold labeling. Appl. Environ. Microbiol. 1992; 58:2302-2307. [PubMed: 1365400]

100. Brantner CA, Remsen CC, Owen HA, Buchholz LA, Collins MLP. Intracellular localization of the particulate methane monooxygenase and methanol dehydrogenase in Methylomicrobium album BG8. Arch. Microbiol. 2002; 178:59-64. [PubMed: 12070770]

101. Keltjens JT, Pol A, Reimann J, Op den Camp HJM. PQQ-dependent methanol dehydrogenases: rare-earth elements make a difference. Appl. Microbiol. Biotechnol. 2014; 98:6163-6183. [PubMed: 24816778]

102. Pol A, Barends TRM, Dietl A, Khadem AF, Eygensteyn J, Jetten MSM, Op den Camp HJM. Rare earth metals are essential for methanotrophic life in volcanic mudpots. Environ. Microbiol. 2014; 16:255-264. [PubMed: 24034209]

103. Tonge GM, Harrison DEF, Knowles CJ, Higgins IJ. Properties and partial purification of the methane-oxidizing enzyme system From Methylosinus trichosporium. FEBS Lett. 1975; 58:293299. [PubMed: 178534]

104. Leak DJ, Dalton H. Growth yields of methanotrophs. 2. A Theoretical analysis. Appl. Microbiol. Biotechnol. 1986; 23:477-481.

105. Anthony C. The $c$-type cytochromes of methylotrophic bacteria. Biochim. Biophys. Acta. 1992; 1099:1-15. [PubMed: 1310872]

106. Cook SA, Shiemke AK. Evidence that a type-2 NADH:quinone oxidoreductase mediates electron transfer to particulate methane monooxygenase in Methylococcus capsulatus. Arch. Biochem. Biophys. 2002; 398:32-40. [PubMed: 11811946]

107. Shiemke AK, Arp DJ, Sayavedra-Soto LA. Inhibition of membrane-bound methane monooxygenase and ammonia monooxygenase by diphenyliodonium: implications for electron transfer. J. Bacteriol. 2004; 186:928-937. [PubMed: 14761987]

108. Shiemke AK, Cook SA, Miley T. Quinols as electron donors for detergent solubilized and membrane-bound methane monooxygenase. J. Inorg. Biochem. 1995; 59:385. 
109. Collins MD, Green PN. Isolation and characterization of a novel coenzyme Q from some methane-oxidizing bacteria. Biochem. Biophys. Res. Commun. 1985; 133:1125-1131. [PubMed: 3936502]

110. Urakami T, Komagata K. Occurrence of isoprenoid compounds in gram-negative methanolutilizing, methane-utilizing, and methylamine-utilizing bacteria. J. Gen. Appl. Microbiol. 1986; 32:317-341.

111. Chen KHC, Wu HH, Ke SF, Rao YT, Tu CM, Chen YP, Kuei KH, Chen YS, Wang VCC, Kao WC, Chan SI. Bacteriohemerythrin bolsters the activity of the particulate methane monooxygenase (pMMO) in Methylococcus capsulatus (Bath). J. Inorg. Biochem. 2012; 111:10_ 17. [PubMed: 22484247]

112. Lee S-K, Nesheim JC, Lipscomb JD. Transient intermediates of the methane monooxygenase catalytic cycle. J. Biol. Chem. 1993; 268:21569-21577. [PubMed: 8408008]

113. Tinberg CE, Lippard SJ. Revisiting the mechanism of dioxygen activation in soluble methane monooxygenase from $M$. capsulatus (Bath): evidence for a multi-Step, proton-dependent reaction pathway. Biochemistry. 2009; 48:12145-12158. [PubMed: 19921958]

114. Banerjee R, Meier KK, Münck E, Lipscomb JD. Intermediate $P^{*}$ from soluble methane monooxygenase contains a diferrous cluster. Biochemistry. 2013; 52:4331-4342. [PubMed: 23718184]

115. Han WG, Noodleman L. Structural model studies for the peroxo intermediate $\mathrm{P}$ and the reaction pathway from $\mathrm{P}->\mathrm{Q}$ of methane monooxygenase using broken-symmetry density functional calculations. Inorg. Chem. 2008; 47:2975-2986. [PubMed: 18366153]

116. Lee S-K, Lipscomb JD. Oxygen activation catalyzed by methane monooxygenase hydroxylase component: proton delivery during the O-O bond cleavage steps. Biochemistry. 1999; 38:44234432. [PubMed: 10194363]

117. Andersson KK, Froland WA, Lee S-K, Lipscomb JD. Dioxygen independant oxygenation of hydrocarbons by methane monooxygenase hydroxylase component. New J. Chem. 1991; 15:411415.

118. Jiang Y, Wilkins PC, Dalton H. Activation of the hydroxylase of sMMO from Methylococcus capsulatus (Bath) by hydrogen peroxide. Biochim. Biophys. Acta. 1993; 1163:105-112. [PubMed: 8476925]

119. Lee S-K, Fox BG, Froland WA, Lipscomb JD, Münck E. A transient intermediate of the methane monooxygenase catalytic cycle containing an $\mathrm{Fe}^{\mathrm{IV}} \mathrm{Fe}^{\mathrm{IV}}$ cluster. J. Am. Chem. Soc. 1993; 115:6450-6451.

120. Shu L, Nesheim JC, Kauffmann K, Münck E, Lipscomb JD, Que L Jr. An Fe ${ }_{2}{ }^{\mathrm{IV}_{\mathrm{O}_{2}}}$ diamond core structure for the key intermediate Q of methane monooxgyenase. Science. 1997; 275:515-518. [PubMed: 8999792]

121. Gherman BF, Baik MH, Lippard SJ, Friesner RA. Dioxygen activation in methane monooxygenase: A theoretical study. J. Am. Chem. Soc. 2004; 126:2978-2990. [PubMed: 14995216]

122. Rinaldo D, Philipp DM, Lippard SJ, Friesner RA. Intermediates in dioxygen activation by methane monooxygenase: A QM/MM study. J. Am. Chem. Soc. 2007; 129:3135-3147. [PubMed: 17326634]

123. Xue G, De Hont R, Münck E, Que L Jr. Million-fold activation of the $\left[\mathrm{Fe}_{2}(\mu-\mathrm{O})_{2}\right]$ diamond core for C-H bond cleavage. Nat. Chem. 2010; 2:400-405. [PubMed: 20414242]

124. Rosenzweig AC. Breaking methane. Nature. 2015; 518:309-310. [PubMed: 25607367]

125. Baik M-H, Newcomb M, Friesner RA, Lippard SJ. Mechanistic studies on the hydroxylation of methane by methane monooxygenase. Chem. Rev. 2003; 103:2385-2419. [PubMed: 12797835]

126. Yoshizawa K, Shiota Y. Conversion of methane to methanol at the mononuclear and dinuclear copper sites of particulate methane monooxygenase (pMMO): a DFT and QM/MM study. J. Am. Chem. Soc. 2006; 128:9873-9881. [PubMed: 16866545]

127. Shiota Y, Yoshizawa K. Comparison of the reactivity of bis $(\mu-o x o) \mathrm{Cu}^{\mathrm{II}} \mathrm{Cu}^{\mathrm{III}}$ and $\mathrm{Cu}^{\mathrm{III}} \mathrm{Cu}^{\mathrm{III}}$ species to methane. Inorg. Chem. 2009; 48:838-845. [PubMed: 19113938] 
128. Shiota Y, Juhasz G, Yoshizawa K. Role of tyrosine residue in methane activation at the dicopper site of particulate methane monooxygenase: a density functional theory study. Inorg. Chem. 2013; 52:7907-7917. [PubMed: 23808646]

129. Woertink JS, Smeets PJ, Groothaert MH, Vance MA, Sels BF, Schoonheydt RA, Solomon EI. A $\left[\mathrm{Cu}_{2} \mathrm{O}\right]^{2+}$ core in $\mathrm{Cu}-\mathrm{ZSM}-5$, the active site in the oxidation of methane to methanol. Proc. Natl. Acad. Sci. U.S.A. 2009; 106:18908-18913. [PubMed: 19864626]

130. Smeets PJ, Hadt RG, Woertink JS, Vanelderen P, Schoonheydt RA, Sels BF, Solomon EI. Oxygen precursor to the reactive intermediate in methanol synthesis by Cu-ZSM-5. J. Am. Chem. Soc. 2010; 132:14736-14738. [PubMed: 20923156]

131. Culpepper MA, Cutsail GE, Hoffman BM, Rosenzweig AC. Evidence for oxygen binding at the active site of particulate methane monooxygenase. J. Am. Chem. Soc. 2012; 134:7640-7643. [PubMed: 22540911]

132. Solomon EI, Ginsbach JW, Heppner DE, Kieber-Emmons MT, Kjaergaard CH, Smeets PJ, Tian L, Woertink JS. Copper dioxygen (bio) inorganic chemistry. Faraday Dis. 2011; 148:11-39.

133. Zlateva T, Santagostini L, Bubacco L, Casella L, Salvato B, Beltramini M. Isolation of the metderivative intermediate in the catalase-like activity of deoxygenated Octopus vulgaris hemocyanin. J. Inorg. Biochem. 1998; 72:211-215.

134. Andrew CR, McKillop KP, Sykes AG. Kinetic studies on the reactions of separated a, b and c subunits of Panulirus interruptus deoxy-hemocyanin with hydrogen peroxide. Biochim. Biophys. Acta. 1993; 1163:17-25. [PubMed: 8476926]

135. Solomon EI, Sundaram UM, Machonkin TE. Multicopper oxidases and oxygenases. Chem. Rev. 1996; 96:2563-2605. [PubMed: 11848837]

136. Wilkinson B, Zhu M, Priestley ND, Nguyen H-HT, Morimoto H, Williams PG, Chan SI, Floss HG. A concerted mechanism for ethane hydroxylation by the particulate methane monooxygenase from Methylococcus capsulatus (Bath). J. Am. Chem. Soc. 1996; 118:921-922.

137. Oldenhuis R, Oedzes JY, van der Waarde JJ, Janssen DB. Kinetics of chlorinated hydrocarbon degradation by Methylosinus trichosporium OB3b and toxicity of trichloroethylene. Appl. Environ. Microbiol. 1991; 57:7-14. [PubMed: 2036023] 

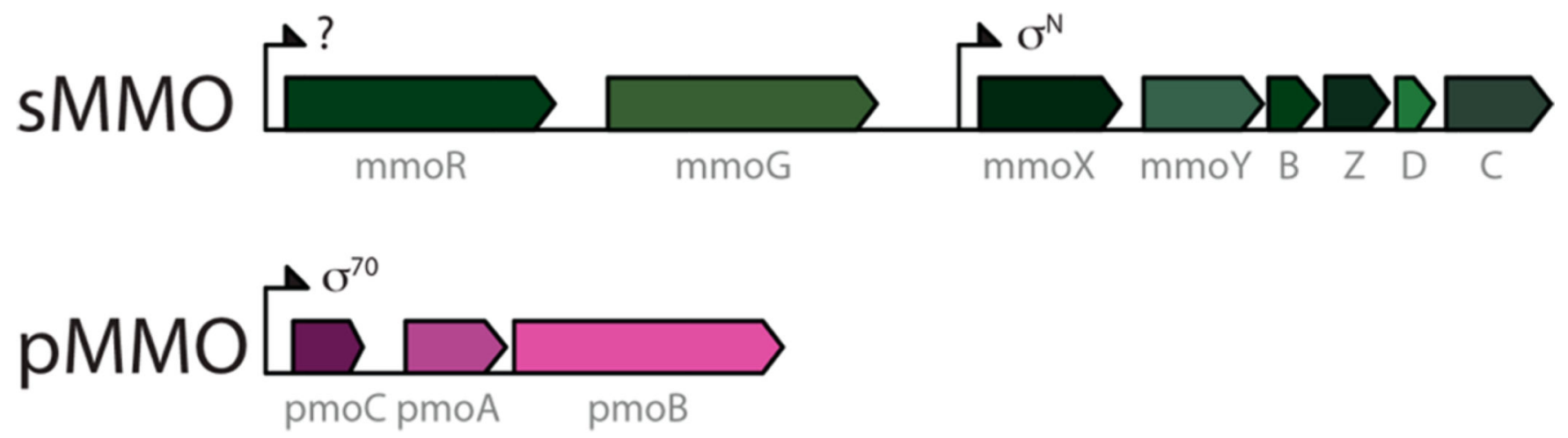

Figure 1.

sMMO and pMMO operons. 

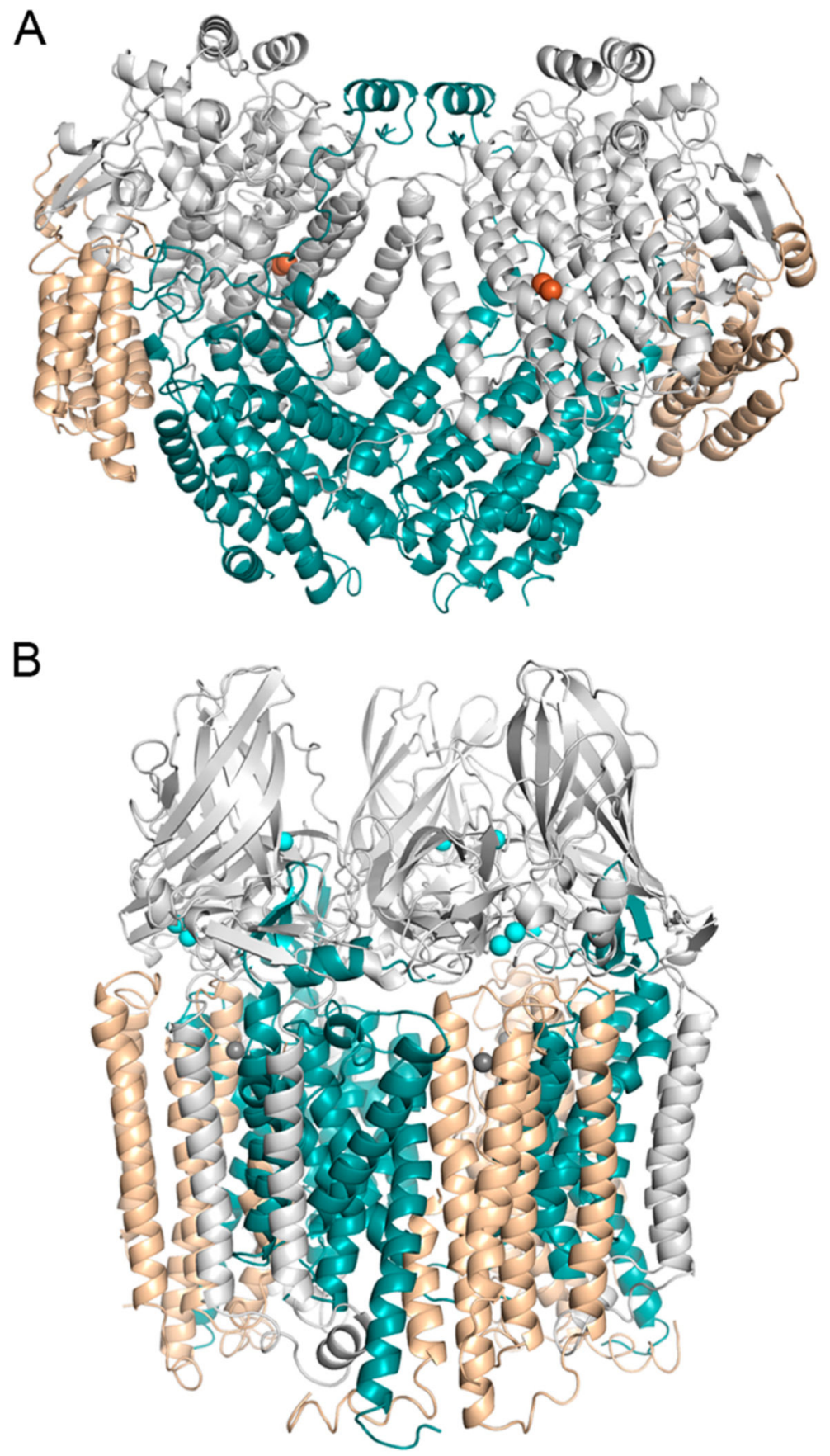

Figure 2.

Overall architecture of MMOs. (A) The sMMO hydroxylase (MMOH, PDB accession code $1 \mathrm{MTY}$ ) with a subunits shown in gray, $\beta$ subunits shown in teal, and $\gamma$ subunits shown in wheat. Each $\alpha_{2} \beta_{2} \gamma_{2}$ dimer contains two diiron active sites (orange spheres). (B) The pMMO trimer (PDB accession code 3RGB) with pmoB subunits shown in gray, pmoA subunits shown in teal, and pmoC subunits shown in wheat. Copper ions are shown as cyan spheres and zinc ions are shown as gray spheres. 


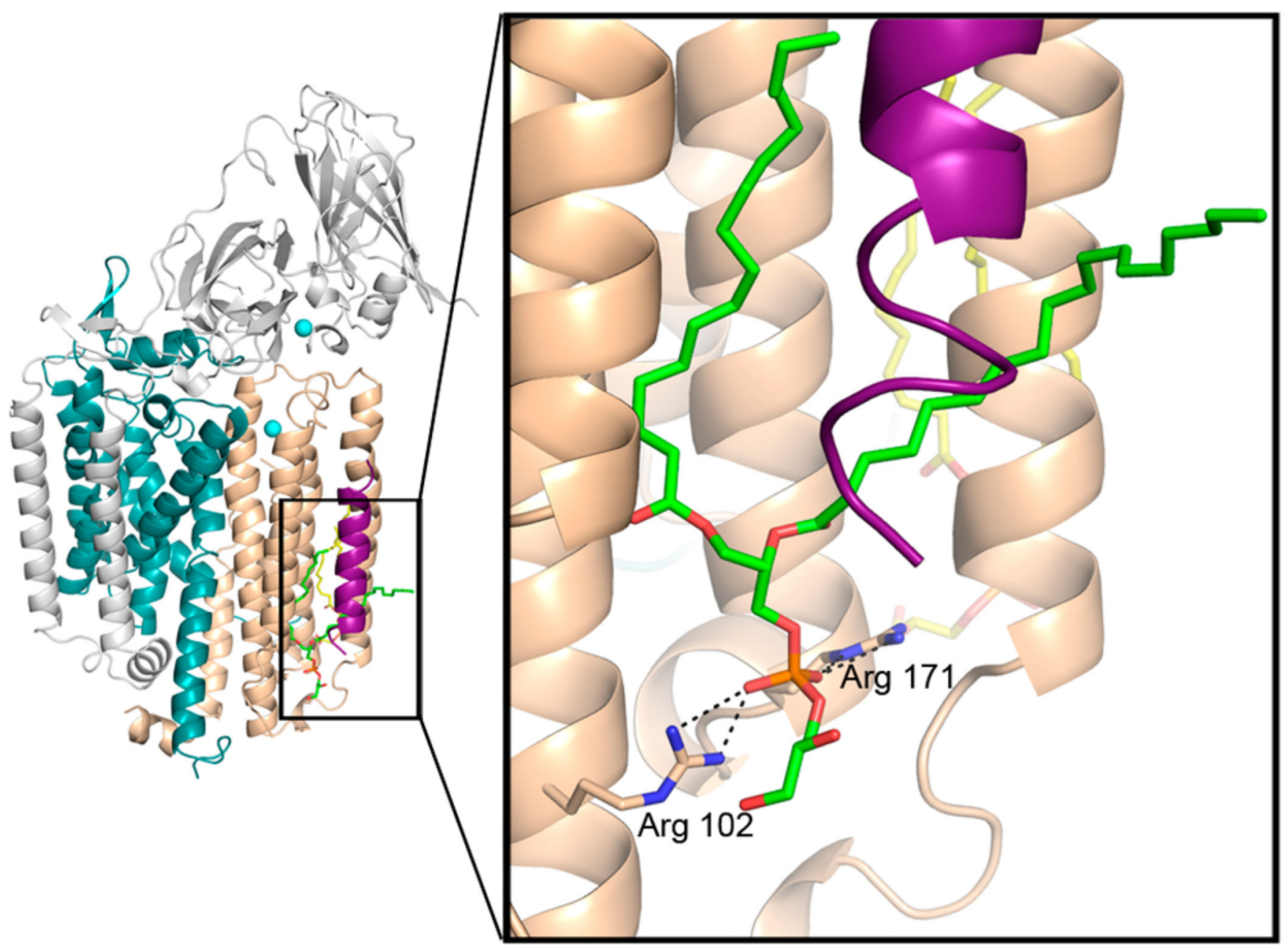

Figure 3.

One a $\beta \gamma$ protomer of Methylocystis sp. strain Rockwell pMMO (PDB accession code 4PHZ) showing the unidentified helix (purple) and two bound lipids (green and yellow). The unidentified helix is also observed in structures of pMMO from M. trichosporium OB3b and Methylocystis sp. strain M. The lipid shown in green forms hydrogen bonds with conserved arginine residues from pmoC and mediates the interaction between pmoC and the mystery helix. 

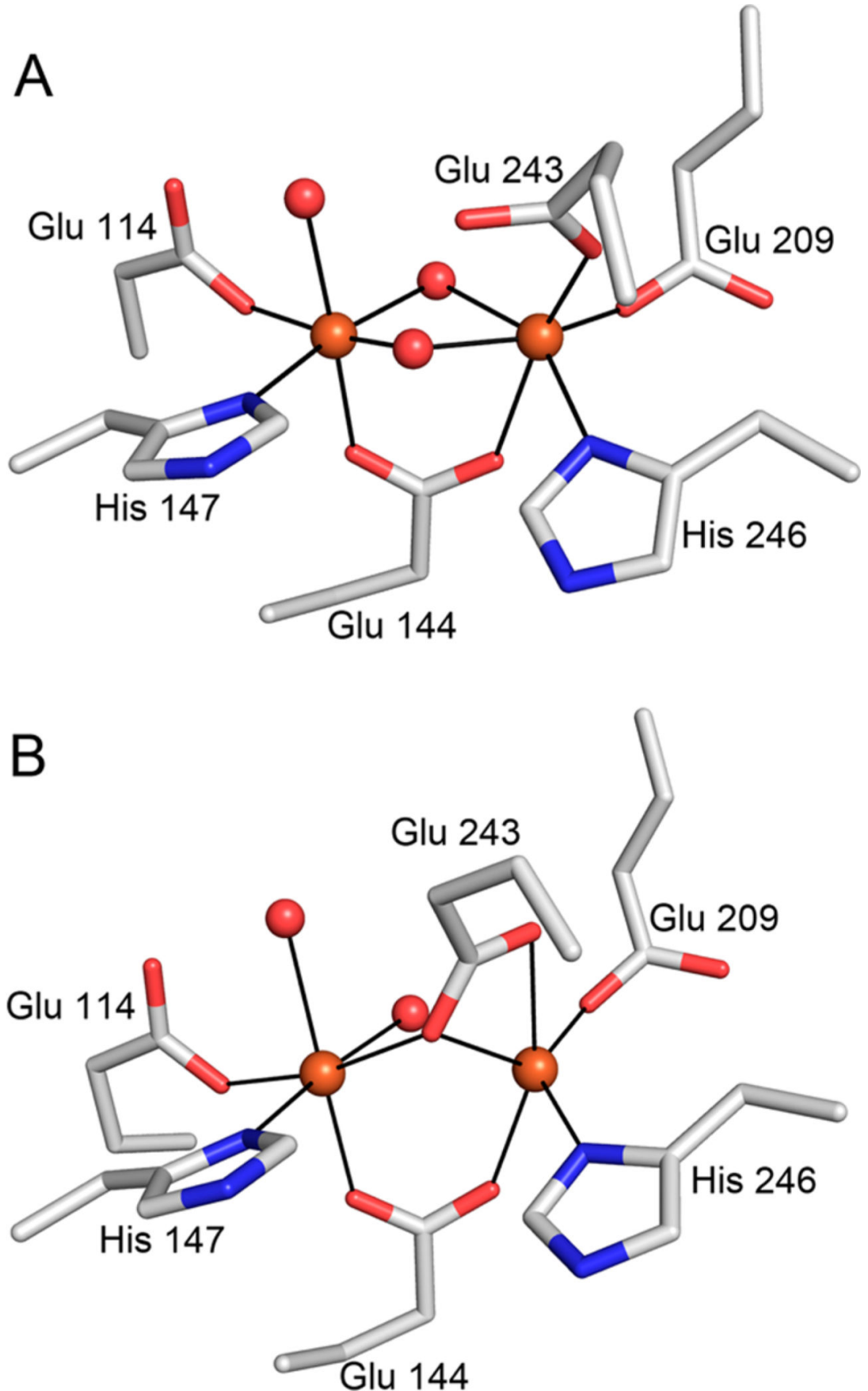

Figure 4.

Active site of sMMO. (A) Oxidized diiron center (PDB accession code 1MTY). (B) Reduced diiron center (PDB accession code 1FYZ). Iron ions are shown as orange spheres and solvent ligands are shown as red spheres. 


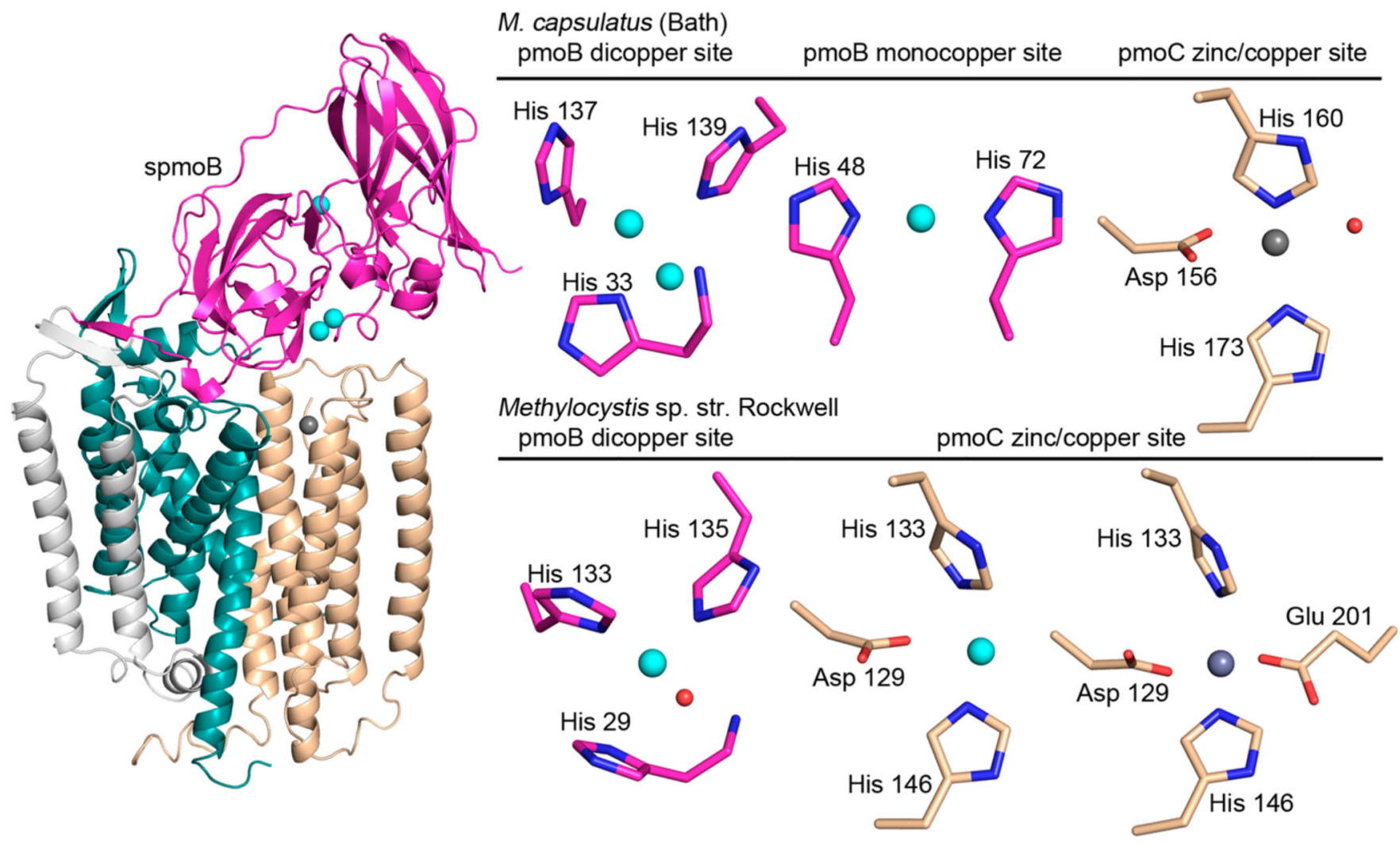

Figure 5.

Metal centers in the pMMO crystal structures. The locations of the dicopper, monocopper, and zinc/copper sites are shown as cyan and gray spheres within a protomer of M. capsulatus (Bath) pMMO (left). In the spmoB protein, two transmembrane helices (gray) linking the periplasmic $\mathrm{N}$ - and $\mathrm{C}$-terminal cupredoxin domains of pmoB (magenta) are replaced with a GKLGGG linker connecting residue 172 to residue 265. The structure of spmoB has not been determined. The $M$. capsulatus (Bath) pMMO structure contains dicopper, monocopper, and zinc sites (top right, PDB accession code 3RGB). In the Methylocystis sp. strain Rockwell pMMO structure (bottom right), the dicopper site is modeled with a single copper ion and a solvent molecule, and the zinc/copper site is occupied by copper (PDB accession code 4PHZ). Soaking the crystals in zinc reveals a fourth ligand to this site, Glu201 (PDB accession code 4PI2). Solvent ligands are shown as red spheres. 


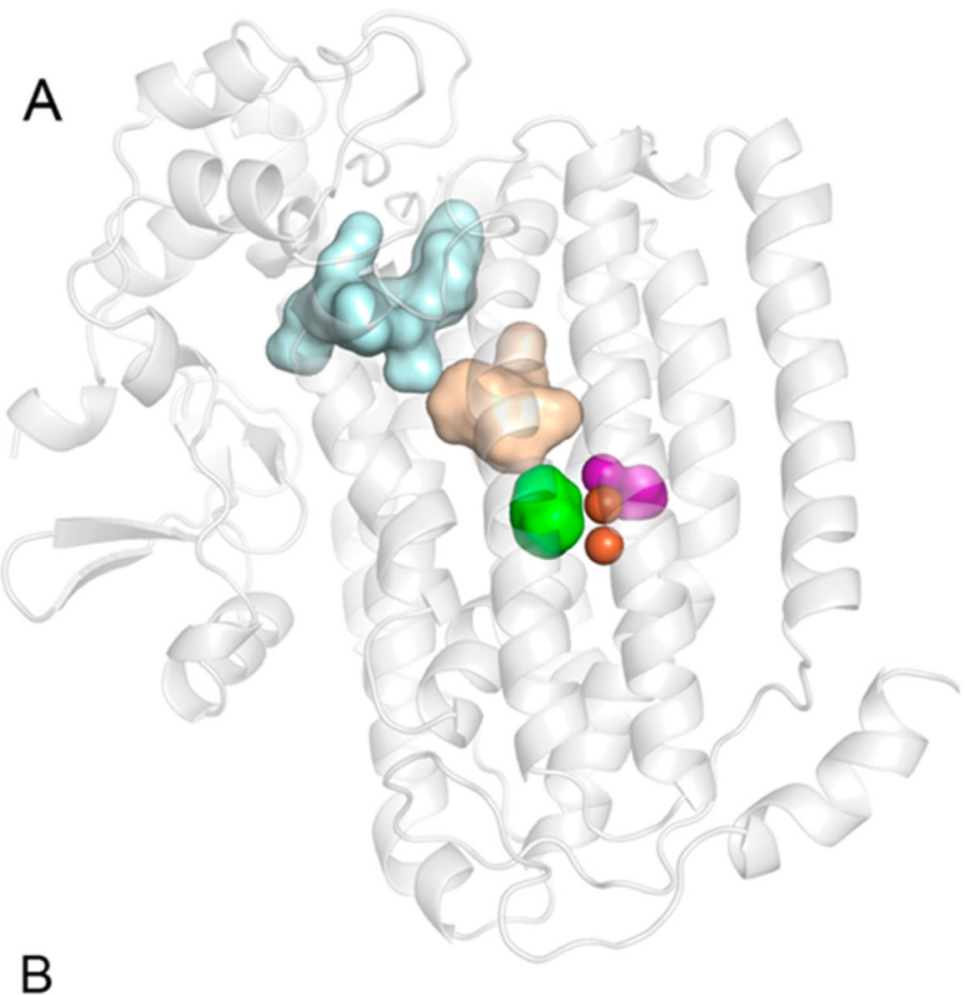

B

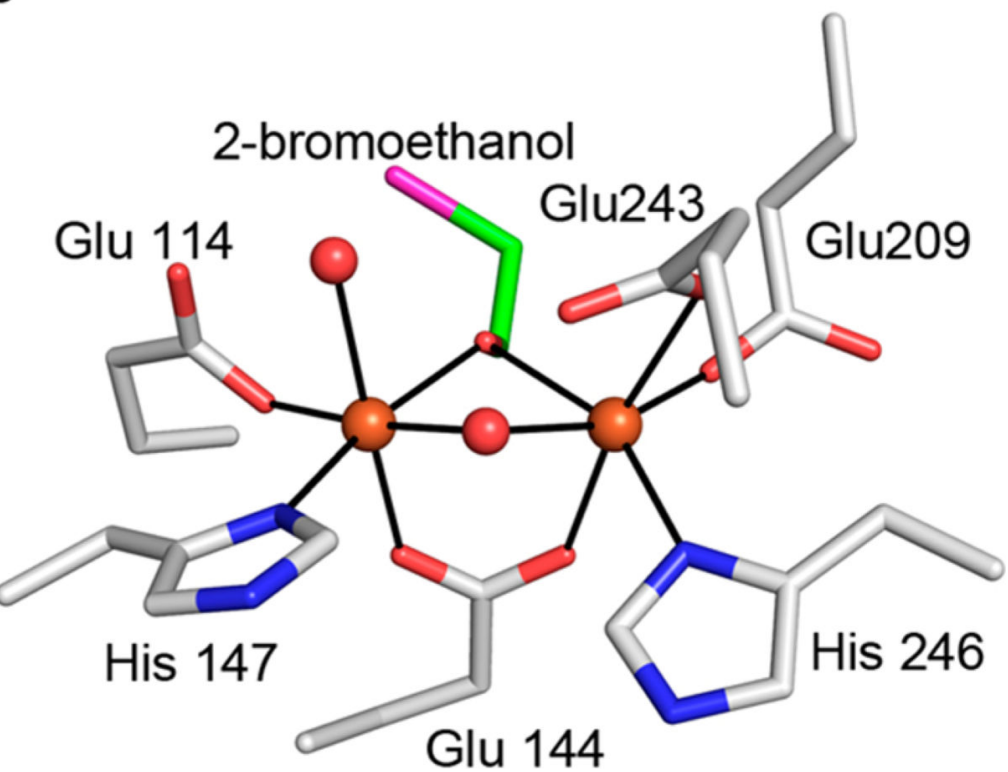

Figure 6.

Substrate binding by MMOH. (A) Three cavities and a pore region connect to the active site: cavity 1 , green; cavity 2 , wheat; cavity 3 , light blue; hydrophilic pore, magenta. The iron ions are shown as orange spheres. (B) Structure of active site with bound 2-bromoethanol (PDB accession code 1XVG). The carbon atoms of 2-bromoethanol are shown in green and the bromine atom is shown in magenta. 

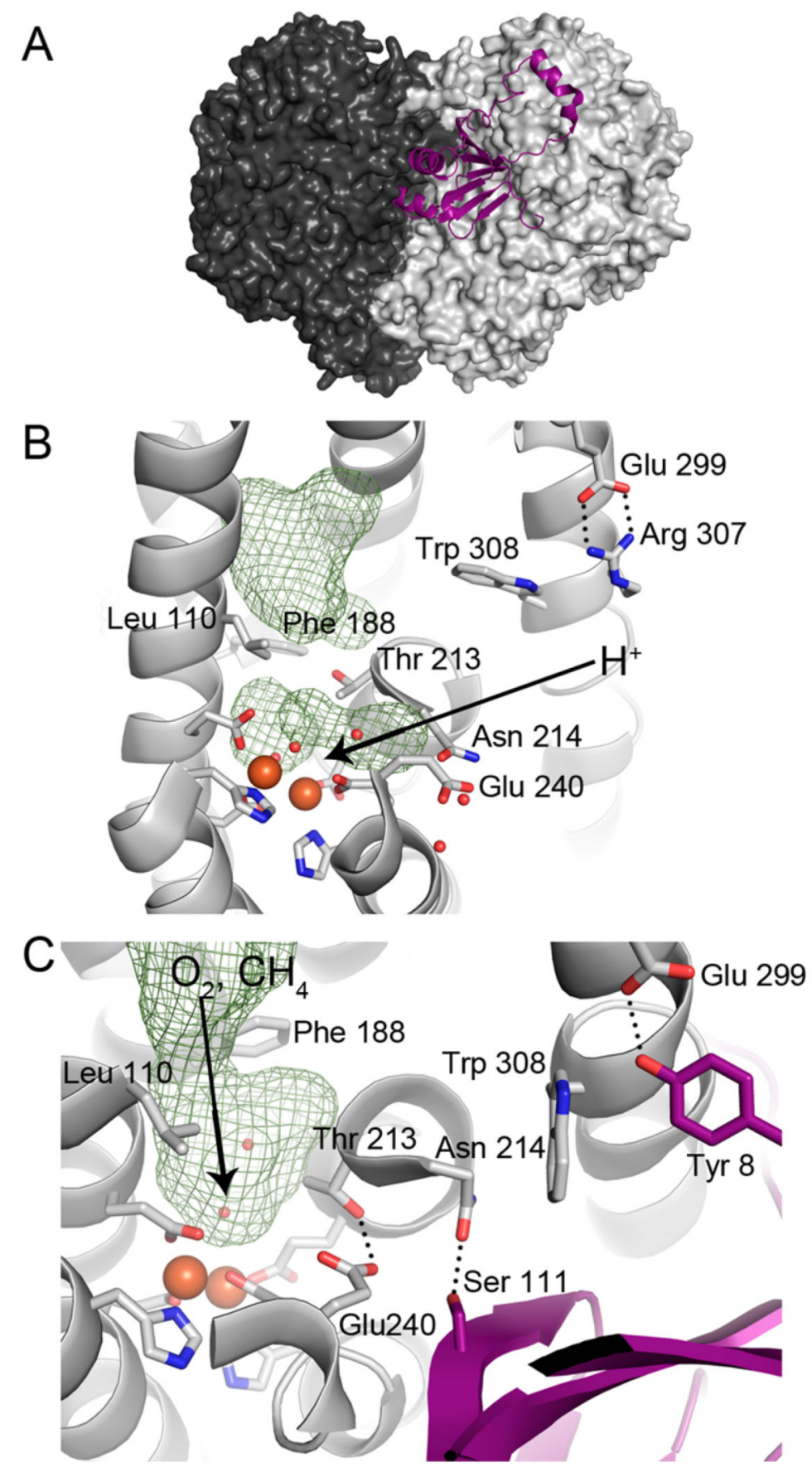

Figure 7.

Structural changes in MMOH upon complexation with MMOB. (A) MMOB (purple cartoon) binds in the canyon region formed by the two $\mathrm{MMOH}$ protomers (black and gray surfaces) (PDB accession code 4GAM). (B) Active site region in uncomplexed MMOH (PDB accession code 1MTY). The hydrophilic pore is open to solvent, and cavities 1 and 2 are separated by Leu110 and Phe188. (C) Active site region in MMOH-MMOB complex (PDB accession code 4GAM). The pore is closed, and conformational changes in Phe188 
link cavities 1 and 2, allowing substrate access to the active site. Cavities are shown as green mesh. 
Table 1

MMO Structures

\begin{tabular}{|c|c|c|}
\hline & $\begin{array}{l}\text { resolution } \\
(\AA)\end{array}$ & $\begin{array}{l}\text { PDB } \\
\text { code }\end{array}$ \\
\hline \multicolumn{3}{|c|}{ Methylococcus capsulatus (Bath) MMOH (hydroxylase) } \\
\hline oxidized $4{ }^{\circ} \mathrm{C}$ & 2.20 & $1 \mathrm{MMO}$ \\
\hline oxidized & 1.96 & 1FZ1 \\
\hline oxidized & 1.70 & $1 \mathrm{MTY}$ \\
\hline reduced in crystal & 2.15 & $1 \mathrm{FYZ}$ \\
\hline anaerobically grown reduced & 2.40 & 1FZ5 \\
\hline mixed valence, reduced in crystal & 2.15 & $1 \mathrm{FZ2}$ \\
\hline anaerobically grown mixed valence & 2.07 & $1 \mathrm{FZ} 0$ \\
\hline methanol soaked & 2.05 & 1FZ6 \\
\hline ethanol soaked & 1.96 & $1 \mathrm{FZ7}$ \\
\hline Xe pressurized & 3.30 & 1FZI \\
\hline Xe pressurized & 2.60 & $1 \mathrm{FZH}$ \\
\hline dibromomethane grown & 2.10 & $1 \mathrm{FZ} 8$ \\
\hline iodoethane grown & 2.30 & 1FZ9 \\
\hline $\mathrm{pH} 8.5$ soaked & 2.38 & $1 \mathrm{FZ4}$ \\
\hline pH 6.2 soaked & 2.03 & $1 \mathrm{FZ3}$ \\
\hline Mn(II) soaked & 2.32 & $1 \mathrm{XMF}$ \\
\hline apo (metal free) & 2.10 & $1 \mathrm{XMG}$ \\
\hline $\mathrm{Co}(\mathrm{II})$ reconstituted & 2.32 & $1 \mathrm{XMH}$ \\
\hline phenol soaked & 1.96 & 1XU5 \\
\hline 6-bromohexanol soaked & 1.80 & $1 \mathrm{XVB}$ \\
\hline 8-bromooctanol soaked & 2.00 & $1 \mathrm{XVC}$ \\
\hline 4-fluorophenol soaked & 2.30 & $1 \mathrm{XVD}$ \\
\hline 3-bromo-3-butenol soaked & 2.40 & $1 \mathrm{XVE}$ \\
\hline chloropropanol soaked & 2.00 & $1 \mathrm{XVF}$ \\
\hline bromoethanol soaked & 1.96 & $1 \mathrm{XVG}$ \\
\hline bromophenol soaked & 2.30 & $1 \mathrm{XU} 3$ \\
\hline \multicolumn{3}{|c|}{ Methylosinus trichosporium OB3b MMOH (hydroxylase) } \\
\hline oxidized & 2.00 & $1 \mathrm{MHY}$ \\
\hline oxidized & 2.70 & $1 \mathrm{MHZ}$ \\
\hline \multicolumn{3}{|c|}{ MMOB, MMOC, and Protein-Protein Complexes } \\
\hline M. capsulatus (Bath) MMOB NMR & & $1 \mathrm{CKV}$ \\
\hline M. trichosporium OB3b MMOB NMR & & $2 \mathrm{MOB}$ \\
\hline $\begin{array}{l}\text { M. capsulatus (Bath) MMOC }[2 \mathrm{Fe}-2 \mathrm{~S}] \text { domain } \\
\text { NMR }\end{array}$ & & 1JQ4 \\
\hline $\begin{array}{l}\text { M. capsulatus (Bath) MMOC FAD/NADH binding } \\
\text { domain NMR }\end{array}$ & & $1 \mathrm{TVC}$ \\
\hline M. capsulatus (Bath) MMOH-MMOB complex & 2.90 & 4GAM \\
\hline pMMO & & \\
\hline
\end{tabular}




\begin{tabular}{|c|c|c|}
\hline & $\begin{array}{l}\text { resolution } \\
(\AA)\end{array}$ & $\begin{array}{l}\text { PDB } \\
\text { code }\end{array}$ \\
\hline M. capsulatus (Bath) pMMO & 2.8 & 1YEW \\
\hline M. capsulatus (Bath) pMMO & 2.8 & $3 \mathrm{RGB}^{a}$ \\
\hline M. trichosporium OB3b pMMO & 3.9 & $3 \mathrm{CHX}$ \\
\hline Methylocystis species strain M pMMO & 2.68 & 3RFR \\
\hline Methylocystis species strain Rockwell pMMO & 2.59 & $4 \mathrm{PHZ}$ \\
\hline $\begin{array}{l}\text { Methylocystis species strain Rockwell pMMO Cu(II) } \\
\text { soaked }\end{array}$ & 3.15 & $4 \mathrm{PIO}$ \\
\hline $\begin{array}{l}\text { Methylocystis species strain Rockwell pMMO Zn(II) } \\
\text { soaked }\end{array}$ & 3.33 & $4 \mathrm{PI} 2$ \\
\hline
\end{tabular}

${ }^{a}$ PDB 3RGB is an improved version of structure 1YEW and should be used as the M. capsulatus (Bath) pMMO model; 1YEW is obsolete. 
Table 2

MMO Turnover Numbers

\begin{tabular}{|c|c|c|c|}
\hline sample & organism & $\begin{array}{l}\text { turnover } \\
\text { number per } \\
\text { active site } \\
\left(\mathrm{s}^{-1}\right)\end{array}$ & reference \\
\hline $\begin{array}{l}\text { cells producing } \\
\text { sMMO }\end{array}$ & M. trichosporium $\mathrm{OB} 3 \mathrm{~b}$ & $>3.5$ & $\begin{array}{l}10,46 \\
137\end{array}$ \\
\hline \multirow{2}{*}{$\begin{array}{l}\text { cells producing } \\
\text { pMMO }\end{array}$} & M. trichosporium $\mathrm{OB} 3 \mathrm{~b}$ & $0.5-2.5^{a}$ & 66 \\
\hline & M. capsulatus (Bath) & $0.5-2.5^{a}$ & 12,67 \\
\hline \multicolumn{4}{|l|}{ purified sMMO } \\
\hline \multirow[t]{2}{*}{ methane } & M. capsulatus (Bath) & $0.2-1.0$ & 44,45 \\
\hline & M. trichosporium $\mathrm{OB} 3 \mathrm{~b}$ & 3.7 & 46 \\
\hline \multirow[t]{2}{*}{ propylene } & M. capsulatus (Bath) & 0.7 & 44,45 \\
\hline & M. trichosporium $\mathrm{OB} 3 \mathrm{~b}$ & 4.4 & 46 \\
\hline \multicolumn{4}{|l|}{$\begin{array}{l}\text { membrane- } \\
\text { bound pMMO }\end{array}$} \\
\hline methane & M. capsulatus (Bath) & $0.05-0.27^{b}$ & 26 \\
\hline \multirow[t]{2}{*}{ propylene } & M. capsulatus (Bath) & $0.033-0.25$ & 12,65 \\
\hline & $\begin{array}{l}\text { M. trichosporium OB } 3 \mathrm{~b} \text {, } \\
\text { Methylocystis sp. str. M, } \\
\text { Methylocystis sp. str. } \\
\text { Rockwell }\end{array}$ & $0.003-0.04$ & 9,26 \\
\hline \multicolumn{4}{|l|}{ purified pMMO } \\
\hline methane & & NA & \\
\hline propylene & M. capsulatus (Bath) & $0.003-0.27$ & 10 \\
\hline
\end{tabular}

${ }^{a}$ Assuming cells are $50 \%$ protein and MMO is $20 \%$ of total protein.

${ }^{b}$ Assuming membrane samples are $80 \%$ pMMO. 